\title{
Application of numerical cladistic analyses to the Carnian-Norian conodonts: a new approach for phylogenetic interpretations
}

\author{
Michele Mazza ${ }^{\mathrm{a} *}$, Andrea $\mathrm{Cau}^{\mathrm{b}}$ and Manuel Rigo ${ }^{\mathrm{c}}$ \\ ${ }^{a}$ Dipartimento di Scienze della Terra “Ardito Desio”, Università degli Studi di Milano, Via Mangiagalli 34, 20133 Milano, Italy; ${ }^{b}$ Museo \\ Geologico "Giovanni Capellini", Alma Mater Studiorum, Università di Bologna, Via Zamboni 63, 40126 Bologna, Italy; 'Department of \\ Geosciences, University of Padova, Via Giotto 1, 35137 Padova, Italy
}

(Received 1 June 2010; accepted 1 February 2011; printed 6 August 2012)

\begin{abstract}
The high intraspecific variability of conodont platform elements in the upper Carnian-lower Norian interval and the proliferation of numerous species in this relatively short time have generated many problems for the understanding of Late Triassic conodont phylogeny, systematics and taxonomy. Since Late Triassic natural assemblages are still unknown, we have applied cladistic methodologies to investigate the evolution of Carnian-Norian conodont platforms and to infer more precise phylogenetic relationships among taxa. Numerical cladistic analysis was undertaken of species belonging to the five Late Triassic genera Paragondolella, Carnepigondolella, Metapolygnathus, Epigondolella and Norigondolella. A taxon-character data matrix describing the distribution of 64 characters amongst two outgroups and 31 ingroup taxa was compiled and processed using PAUP* 4.1. Our analyses show the evolutionary and systematic value of certain morphological characters, and lead to a reinterpretation of the phylogenetic position of the genera considered: Metapolygnathus, Epigondolella and Norigondolella are monphyletic taxa, Paragondolella represents a polyphyletic assemblage of basal members of the ingroup, and Carnepigondolella a paraphyletic group including primitive forms of the Metapolygnathus and Epigondolella lineages. Our analyses also clarify the systematic position of 'Metapolygnathus communisti B' and confirm the existence of four new species: Carnepigondolella angulata sp. nov., Epigondolella heinzi sp. nov., Epigondolella miettoi sp. nov. and Norigondolella trinacriae sp. nov.
\end{abstract}

Keywords: conodonts; cladistics; phylogeny; platforms; Carnian-Norian; Late Triassic

\section{Introduction}

The taxonomy and phylogeny of upper Carnian to lower Norian conodont platform elements is rather problematic due to the large number of different forms occurring in this relatively short time interval. The high intraspecific variability that affects many conodont taxa, together with the abundance of synonymous species, has prevented the establishment of a phylogenetic scheme for Carnian-Norian conodonts.

The wide proliferation of different conodont morphotypes in the Tethys is most likely the consequence of sudden climatic variations that took place during the late Carnian. The Carnian was in fact a time of biological crisis for marine organisms, such as ammonoids, crinoids and bryozoans (Simms \& Ruffell 1989; Simms et al. 1995), affecting carbonate platforms and their productivity. Conodonts were also affected by a strong episode of crisis around the Julian (lower Carnian)/Tuvalian (upper Carnian) boundary when a humid climate pulse, known as the Carnian Pluvial Event, occurred in all Triassic oceans (Rigo et al. 2007; Rigo \& Joachimski 2010; Preto et al. 2010 and references therein). The lower Carnian (Julian) conodont fauna is mainly characterized by relict Ladinian forms (e.g. Budurovignathus spp., Gladigondolella spp., Paragondolella spp.), together with some new taxa belonging to the Auriformis group (Rigo 2006; Rigo et al. 2007). At the Julian/Tuvalian boundary (early/late Carnian), a marked conodont mass extinction occurred (Rigo et al. 2007; Rigo \& Joachimski 2010): all the relict Ladinian forms disappeared and only a few species belonging to the Auriformis group and to the genus Paragondolella persisted. After the end of this climatic perturbation, when arid conditions were restored in the early Carnian, conodonts recovered and the genus Paragondolella rapidly radiated to give rise to several new genera: Carnepigondolella, Epigondolella, Metapolygnathus and Norigondolella. This is the last significant conodont radiation before the final extinction of the class Conodonta in the earliest Jurassic (Pálfy et al. 2007), and it seemingly produced a proliferation of a large number of morphotypes and transitional forms within a relative short time interval, deeply complicating the taxonomy of Late Triassic conodonts.

\footnotetext{
*Corresponding author. Email: mazza_michele@yahoo.it
} 
A traditional phenetic approach has not been able to provide a complete solution to the taxonomic issues associated with this rapid conodont radiation, or to produce a complete phylogenetic model including all Carnian-Norian taxa. The objective of this paper is thus to use cladistic methods as an alternative approach to understand better the morphological evolution of Carnian-Norian conodont platform elements. We believe that the application of a nonparametric statistical method to investigate morphological relationships of these taxa may provide a sounder basis for wider phylogenetic interpretations and allow the reinterpretation of the systematic position of some problematic taxa. The application of numerical cladistic analysis represents an innovative approach to the study of conodonts evolution, since use of cladistic methodology has been almost neglected in this fossil group.

\section{The cladistic approach}

Numerical methods of cladistic analysis have been used only very recently to study conodont relationships and have been applied only to the entire apparatus of the conodont animal (Donoghue 2001; Zhang \& Barnes 2004; Wickström \& Donoghue 2005; Donoghue et al. 2008).

Unfortunately, the original structure of the Late Triassic conodont apparatuses is still unknown as natural clusters of Carnian-Norian conodonts have never been recovered. Some reconstructions of the apparatuses of Late Triassic genera have been proposed (Orchard 2005), but these interpretations are debated amongst specialists since they are modelled on a Middle Triassic Neogondolella natural assemblage (Rieber 1980; Orchard \& Rieber 1999). Given the uncertainty of these reconstructions we focus here on the results of a cladistic analysis of conodont P1 elements (sensu Purnell et al. 2000). This alternative approach to the study of the phylogenetic relationships among Upper Triassic conodonts may be tested when better data on apparatus reconstructions become available.

The application of cladistic methods to conodont platforms may help in the study of the complex palaeontology and biostratigraphy of conodonts since, as argued by Farris (1977, 1979a, b, 1980, 1982, 1983), parsimoniously grouping by synapomorphy (i.e. shared derived character states) provides a more informative classification than using mere similarity (phenetics). In fact, a cladogram may describe more accurately character state changes and distribution in the evolutionary tree than a simple phenogram.

\section{Previous work}

As mentioned above, only a few conodont taxa survived the global biological crisis triggered by the Carnian Pluvial Event which affected Triassic oceans at the Julian/Tuvalian boundary: Paragondolella polygnathiformis, P. praelindae,
Carnepigondolella baloghi, C. nodosa s.s., Cornudina sp. nov. A of Orchard (1991a) and the genus Neocavitella. After this event the last evolutionary conodont radiation occurred (Rigo et al. 2007; Rigo \& Joachimski 2010).

Previous studies on changes in platform morphology during the late Carnian (Tuvalian) (Orchard 1983, 1991a, b, 2007; Mazza \& Rigo 2008) have revealed a series of evolutionary patterns that are common to all Late Triassic conodonts (see also Kozur 1989, 2003). These trends, emerging cyclically in the superfamily Gondolelloidea from the Late Carboniferous to the Late Triassic after a biological crisis, comprise: (a) progressive forward shifting of the pit; (b) gradual shortening of the platform; (c) development of nodes on the platform margins and the evolution of nodes into denticles; and (d) gradual prolongation of the keel behind the pit. Following these evolutionary patterns, Paragondolella polygnathiformis and P. praelindae are the only two gondolelloids surviving the Julian/Tuvalian crisis, followed by further conodont evolution in the Tuvalian (see also Rigo et al. 2007). These two species may be thus considered as the most probable common ancestors of the new taxa that proliferated during the late Carnian-early Norian. Newly arising taxa belong mainly to four genera: Carnepigondolella, Metapolygnathus, Epigondolella and Norigondolella. Following the important taxonomic revision of upper Triassic conodonts by Orchard (1991a,b), studies on Carnian-Norian conodonts have increased considerably only during the last 10 years, when much more interest has focused on the definition of Late Triassic (e.g. Norian) GSSPs (Global Boundary Stratotype Section and Point). These works have improved biostratigraphical knowledge of this interval by establishing several new species and investigating their possible phylogenetic relationships. Here we summarize the phylogenetic hypothesis proposed for Tethyan conodonts:

1. Metapolygnathus is considered the direct descendant of Paragondolella (Kozur 2003). This relationship is suggested by Metapolygnathus praecommunisti, which represents a transitional form between the two genera, showing intermediate features between $P$. noah, the last representative of genus Paragondolella, and M. communisti (Mazza et al.2010,2011), the type species of the genus Metapolygnathus.

2. Carnepigondolella was established by Kozur (2003) and defined as a monophyletic group that includes all primitive representatives of the Epigondolella lineage (Kozur 2003; Noyan \& Kozur 2007). Epigondolella orchardi, which shows intermediate characters between C. pseudodiebeli and E. quadrata (Kozur 2003), was identified as a transitional species between the two genera.

3. The precise systematic position of the genus Norigondolella is uncertain: this genus ranges from the upper Carnian to the middle-upper Norian but its 
plesiomorphic features (the terminal pit position, the long platform margins and the absence of platform ornamentation) place this species closer to Ladinian than to Norian genera. A close phylogenetic relationship with the genus Paragondolella is thus very probable (Orchard 1991a); Kozur (1980, 1990) proposed $P$. oertlii as the immediate forerunner of Norigondolella navicula, the first species of this genus.

Unfortunately, a detailed phylogeny of upper Carnian-lower Norian conodonts has never been proposed. In Fig. 1 we reproduce the phylogenetic hypotheses discussed above. The figure is principally meant to show graphically the relationships among the genera; many species are missing since a lot of them are still incertae sedis and no phylogenetical relationships have yet been proposed.

\section{Material and methods}

\section{Material}

The cladistic analyses have been conducted entirely on material from the Pizzo Mondello section (Sicani Mountains, Italy), a 430-metre thick continuous succession of pelagic limestones ranging from upper Carnian to Rhaetian (Upper Triassic), named Calcari con selce (or Halobia Limestone auctorum; Cherty Limestone, Muttoni et al. 2001, 2004; Guaiumi et al. 2007). Conodonts have been studied in detail and with high resolution sampling from the basal $143 \mathrm{~m}$ of the succession, which ranges from upper Carnian (Tuvalian) to lower Norian (Lacian) (see also Mazza et al. 2010).

Biostratigraphic correlation of the Pizzo Mondello section with other complete Upper Triassic Tethyan sections (i.e. Pignola 2 section, Lagonegro Basin, Italy; Silická Brezová, Slovakia; Feuerkogel, Austria; and three Turkish sections at Bölücektasi Tepe, Kavaalani and Erenkolu Mezarlik 2; see Mazza 2010) have shown that the section contains a complete conodont record representative of the Tethyan realm, assuring that the cladistic analyses were not conducted on endemic species or isolated populations. The only exception is represented by the absence of two species of the genus Norigondolella, N. navicula and N. hallstattensis, in the lower Norian of the Pizzo Mondello section. However, the genus Norigondolella is established as a facies-controlled taxon (Kozur 2003) and is thus affected by clear provincialism.

\section{Outgroup choice}

The selection of the outgroup species is the only part of the cladistic analysis in which a priori assumptions of the relationships among taxa was applied. Since an outgroup species should be the ancestor of the ingroup taxa or, at least, have close relationships with them, a priori knowledge at this stage is inevitable. In this study, the species considered as possible outgroup taxa are Paragondolella polygnathiformis and P. praelindae. Both of these species range from the lower Carnian (Julian) and, being the only two Paragondolellae surviving the Julian/Tuvalian crisis (Rigo et al. 2007), they are the two most plausible direct common ancestors of the taxa proliferating during the upper Carnian (Tuvalian). An extended discussion about outgroup choice is given in the Results section below.

\section{Ingroup taxa}

Ingroup species belong to the five dominant late Carnian/early Norian genera Paragondolella, Carnepigondolella, Metapolygnathus, Epigondolella and Norigondolella. Since the cladistic analyses presented here are intended to reconstruct evolutionary patterns and relationships of Tethyan conodonts after the radiation following the Carnian Pluvial Event, some of the endemic North American taxa are excluded from the analyses due to their absence in the Tethys.

All of the ingroup species have their first appearance datum (FAD) in the upper Carnian (Tuvalian) or the lower Norian (Lacian). Carnepigondolella nodosa is here considered because of its Tuvalian occurrence. The stratigraphical range of this species has been problematic since its establishment, due to the poor illustration of the species given by its author (Hayashi 1968). The age of the holotype is, in fact, uncertain (late Ladinian to early Norian, according to the conodont fauna illustrated in Hayashi 1968), and several authors have attributed to this species a large variety of forms from the Julian to the Tuvalian. A recent study of the holotype by Kozur (see Kozur 2003; Noyan \& Kozur 2007) revealed it to be more similar to the Julian morphotype than to the Tuvalian forms. However, further careful studies of the $C$. nodosa group have shown some overlap between the two forms (Moix et al. 2007), since the Julian morphotype is present also in unequivocal Tuvalian strata in the Mufara Formation of the Panormide and Imerese domains of north-western Sicily (Martini et al. 1991) and in the Calcari con Selce of the Pizzo Mondello section in western Sicily. The Pizzo Mondello section itself yields specimens of the $C$. nodosa group and detailed taxonomic studies (Mazza 2010) confirmed the morphological differences between the Tuvalian morphotype and the holotype, which is more similar to the Julian forms in accordance to Kozur (2003). We agree with Moix et al. (2007) and Noyan \& Kozur (2007) who considered the two C. nodosa morphotypes as different species and, thus, only the Tuvalian form is employed in the cladistic analyses.

\section{Character definitions}

The morphology of conodont platform elements has been analysed using the guidelines and the structural terminology illustrated in the Treatise (Sweet 1981). All three views 


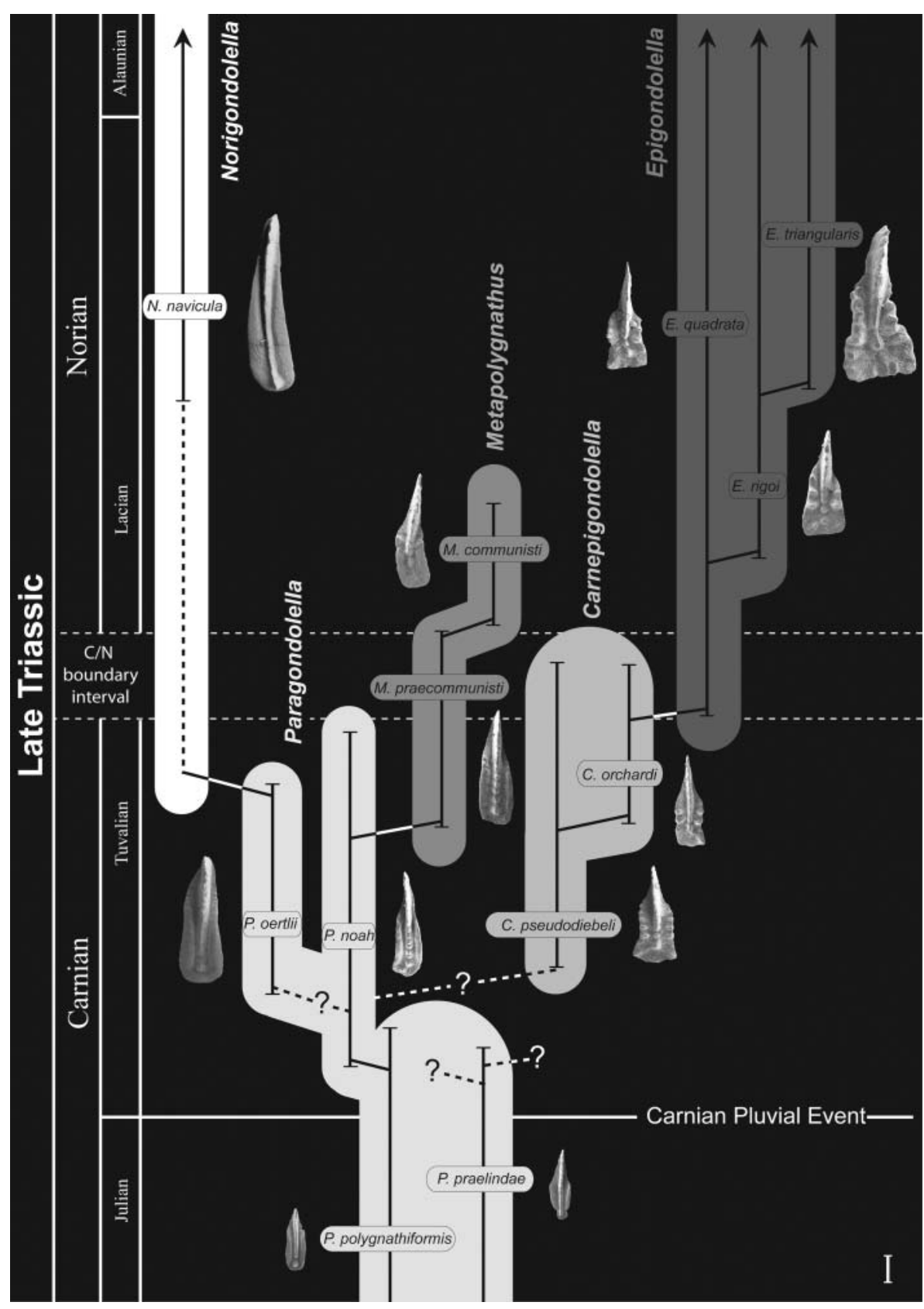

Figure 1. Reconstruction of the phylogeny of the upper Carnian-lower Norian conodonts, based on the phylogenetic relationships proposed in previous works (see the text for details). This scheme is mainly conceived to show the relationships among the genera supposed until now; the phylogenetic relationships among species are reported only when possible. The conodont ranges are indicative and based on the Tethyan occurrences of the taxa. The SEM microphotographs of Norigondolella navicula are from Channel et al. (2003, fig. A2/15), Paragondolella polygnathiformis from Celarc \& Kolar-Jurkovšek (2008, fig. 7/5a), while all the others specimens from the Pizzo Mondello collection. All the specimens represented are at the same scale (the scale bar is $200 \mu \mathrm{m}$ ).

(lower, upper and lateral) have been thoroughly investigated in order to capture all the morphological features that may distinguish the taxa (Fig. 2).

The particular growth pattern of these conodont elements, characterized by the outer apposition of striae (Donoghue 1998, p. 643), makes their morphology subject to considerable variation during ontogeny. For this reason, only adult conodont specimens have been considered in our analyses, whereas juvenile and super-adult growth stages have been disregarded. In addition to the relative size of the entire element, characters that are variable in juvenile forms include the number of blade denticles, their degree of 
fusion, and the size and number of platform nodes or denticles. In super-adult stages, by contrast, ornamentation is the most variable feature. During growth, platform margins progressively thicken, with extreme increases in the superadult forms. As a consequence, nodes or denticles that occur on the platform become coalescent, obliterating the ornamentation that was evident in the adult stage. The mature growth stage (i.e. the adult stage) is thus the best to observe the diagnostic characters of a given species.

The complex morphological features of the platform have been atomized into a series of relatively simpler character statements. Each character statement was formalized in order to describe a single condition expressed by only two mutually exclusive and non-overlapping character states, in which ' 0 ' indicates the plesiomorphic state and ' 1 ' the derived state. Multi-state, ordered or weighted characters have been avoided as they imply a priori knowledge of the transformational processes between the character states.

Dashes are used to indicate the inapplicability of a character to a taxon. The notation (01) is used when a poly-

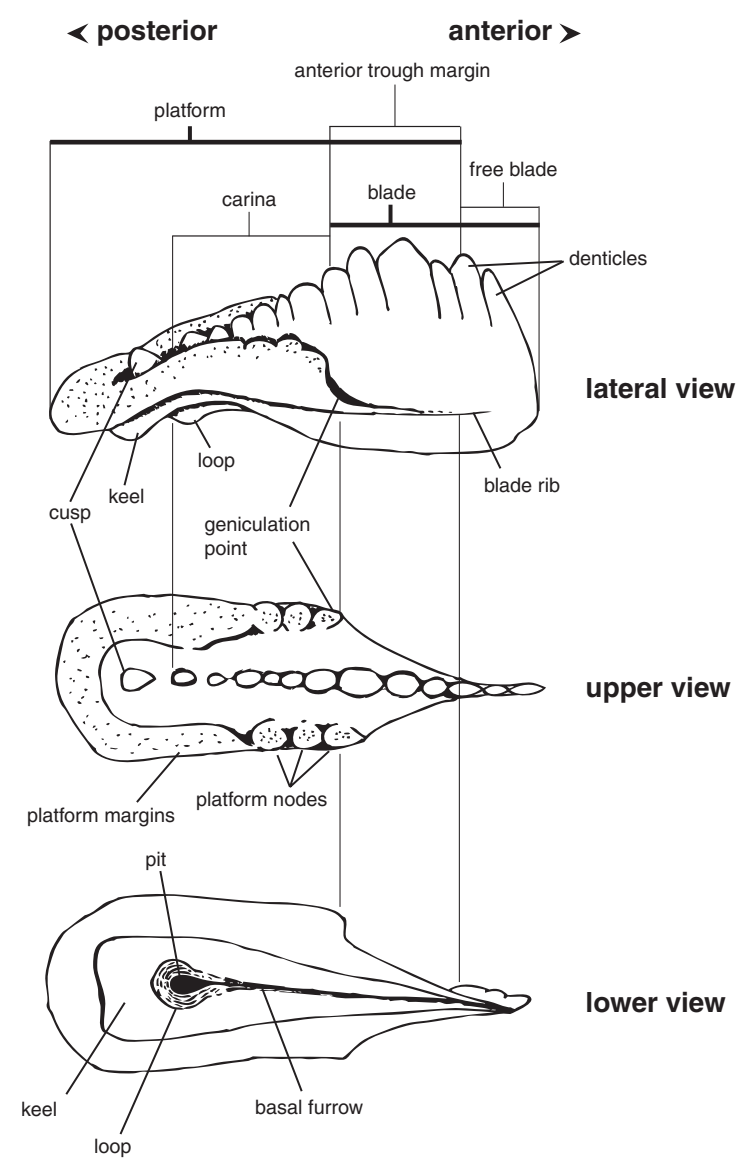

Figure 2. Orientation and main morphological and structural terms used in the description of the morphology of the conodont platform elements. morphic character is present. Ontogenetic morphological variations were not scored as polymorphic characters; only states present in adult stages were scored.

The list of characters considered in each view, with state descriptions, is given in the Online Supplementary Material. Character statement definitions follow Sereno (2007). Since the structural terminology used is the same illustrated in the Treatise (Sweet 1981, pp. W60-W67), the single structural elements are not described. Remarks have been added to the character list when necessary. A graphical representation of the morphological elements considered is given in Fig. 2, while a selection of character states is illustrated in Figs 3 and 4.

\section{Results}

The data matrix, comprising 64 character statements among two outgroup and 31 ingroup taxa (Table 1 of the Online Supplementary Material), was processed using PAUP* 4.1 (Swofford 2002). Because of the large number of taxa included in our study, the Implicit Enumeration Strategy was avoided. The data matrix was processed using alternatively Paragondolella polygnathiformis and $P$. praelindae as outgroups. We performed 1000 Heuristic Search replicates, each analysis starting via stepwise random addition sequence. The branch-swapping algorithm used was TreeBisection-Reconnection. The analysis recovered nine most parsimonious trees (MPTs), 213 steps long each, with a Consistency Index (excluding uninformative characters) of 0.4660 , and a Retention Index of 0.7257 .

The unrooted diagram of the relationships among all the included taxa (Fig. 5) shows three distinct lineages leading to the genera Epigondolella, Metapolygnathus and Norigondolella. No potentially monophyletic clades including only the species referred to Carnepigondolella or Paragondolella were recovered. The two conodonts previously considered as the most probable common ancestors of the ingroup taxa, $P$. polygnathiformis and $P$. praelindae (see 'Outgroup choice'), are placed close to the junction of the three monophyletic clades, confirming their validity as possible outgroups.

For each node of the two MPTs rooted on the two different outgroup taxa, the Bremer Support (Bremer 1988) was also calculated using TNT vers. 1.0 (Goboloff et al. 2008) (Fig. 6).

\section{Discussion}

\section{Unrooted topology and effects of outgroup selection}

As already mentioned, the unrooted diagram recovered three potentially monophyletic lineages leading to 

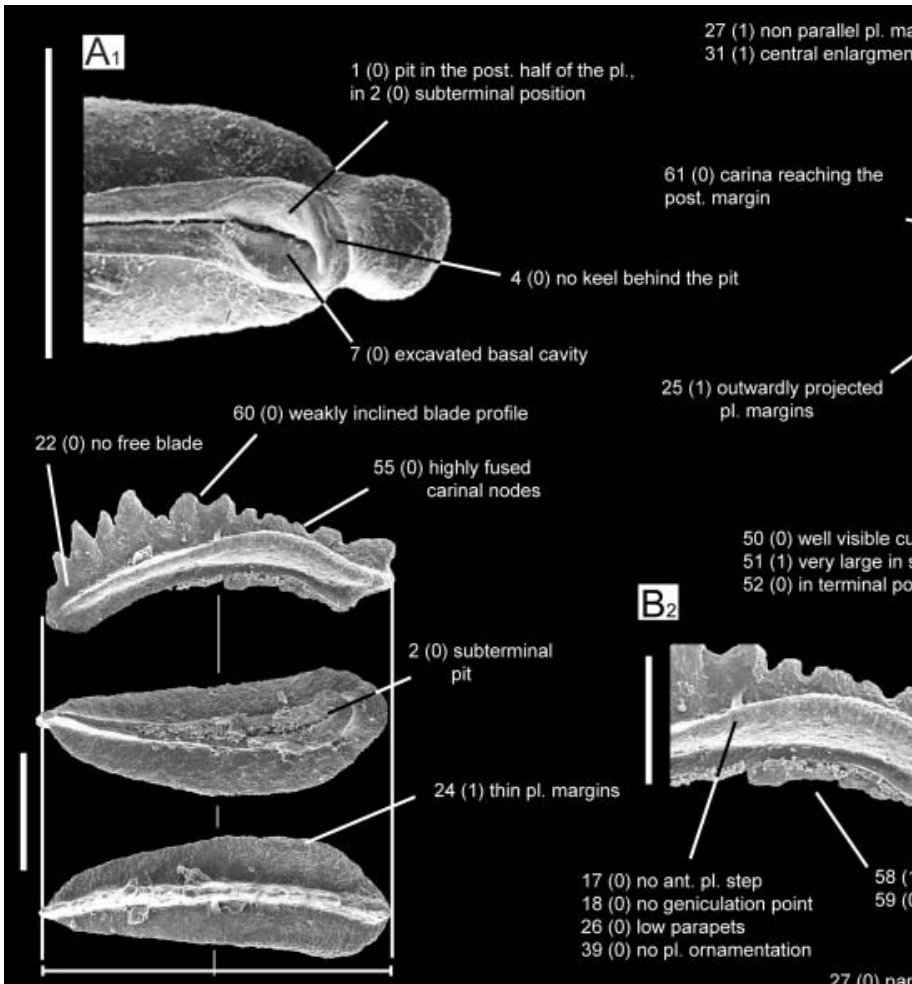

25 (1) outwardly projected pl. margins

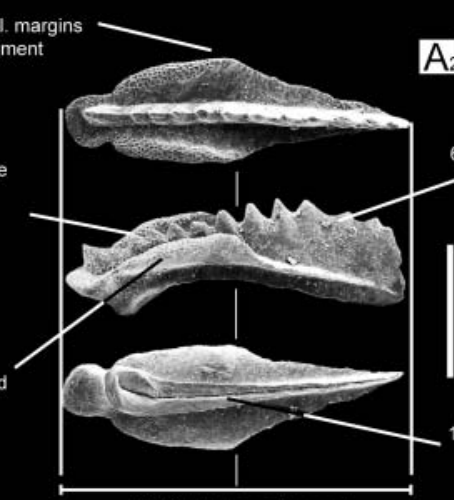

$\mathrm{A}_{2}$

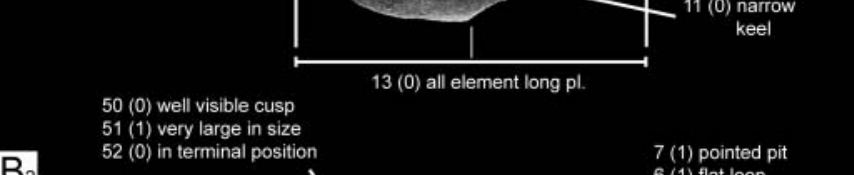

$\mathrm{B}_{2}$

$\mathrm{B}_{1}$

$3(0)$ all element long $\mathrm{pl}$

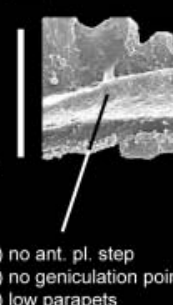

in termina in size

6 (0) low parapets

$39(0)$ no pl. ornamentation

58 (1) not straight profile

6 (1) flat loop

poorly fused
blade denticles

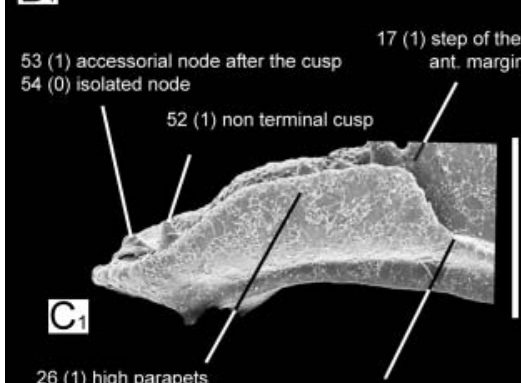

26 (1) high p

18 (1) geniculation point

\section{C.}
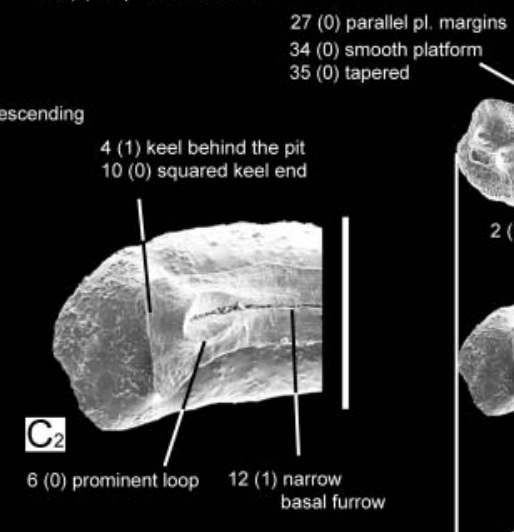

55 (1) moderately fused carinal nodes

$\mathrm{B}_{3}$
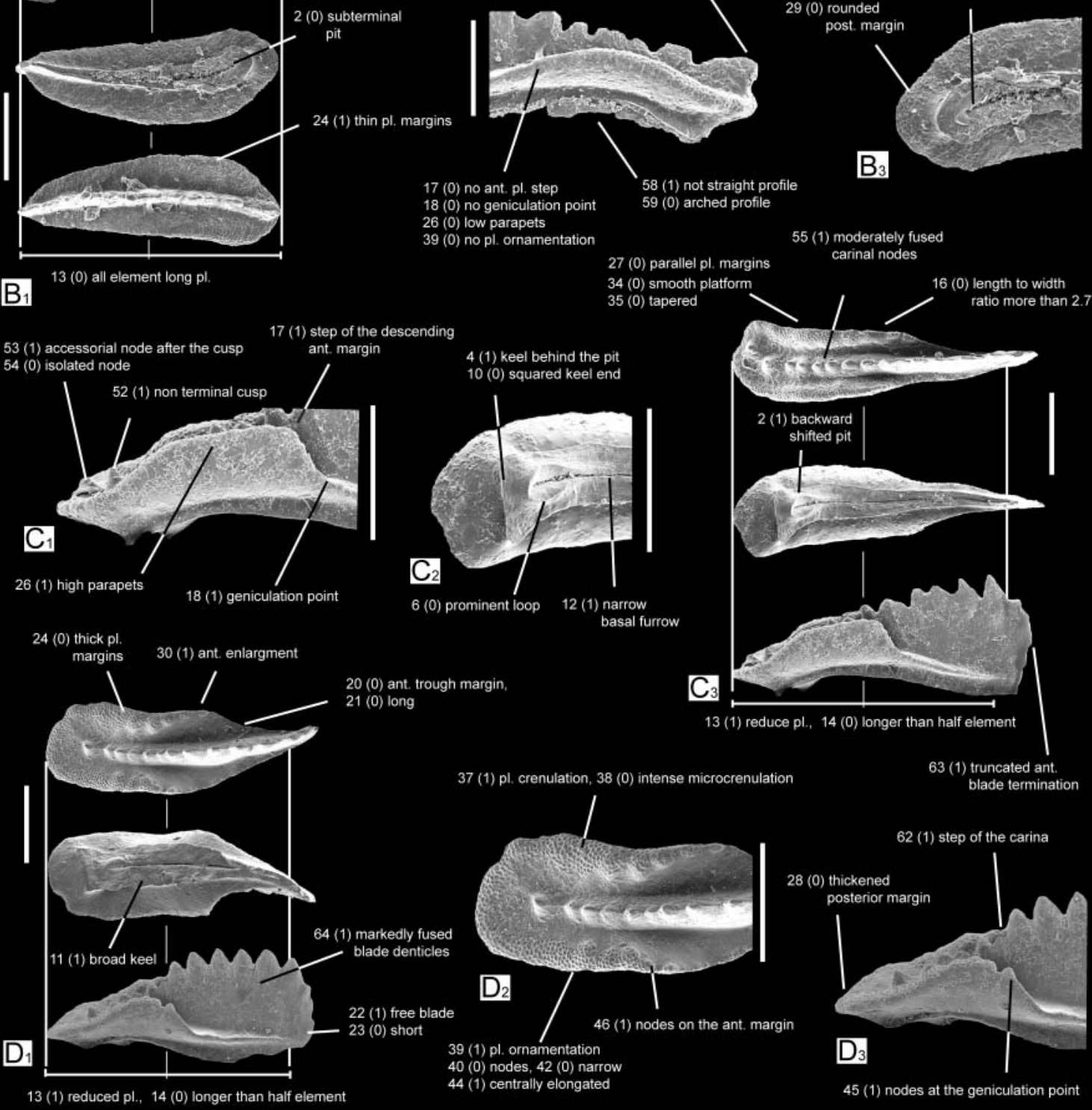

$\mathrm{C}_{3}$

13 (1) reduce pl., $14(0)$ longer than half element

length to width ratio more than 2.7
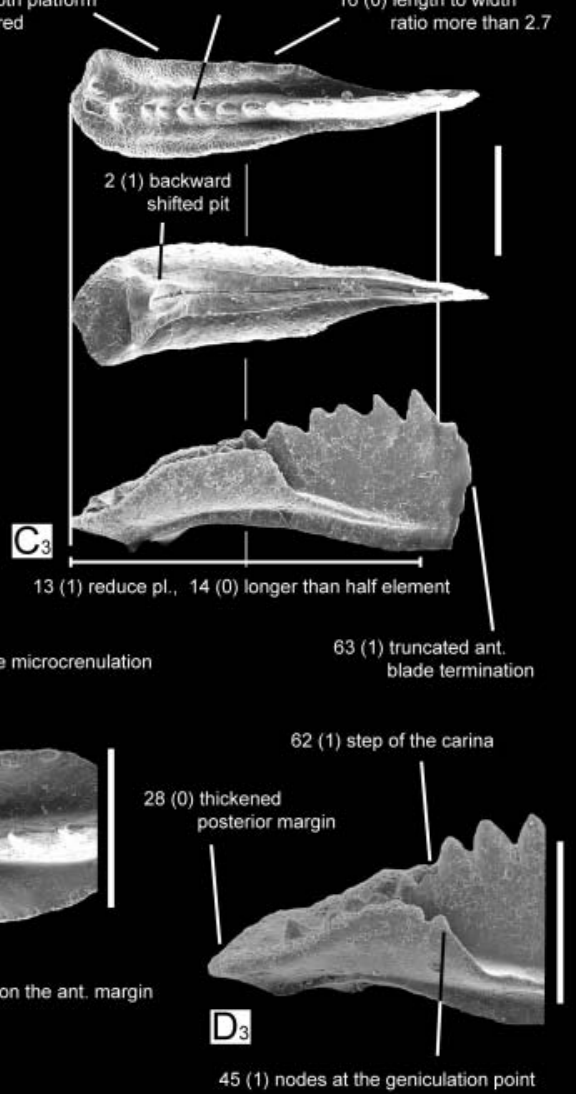

Figure 3. Representation of the morphological characters used in the cladistic analyses and selected character states (other characters are illustrated in Fig. 4). The most representative species have been chosen to illustrate the characters. A, Paragondolella praelindae; B, Navicula cf. navicula; $\mathbf{C}$, Paragondolella noah; D, Carnepigondolella nodosa. All the SEM microphotographs are from specimens of the Pizzo Mondello collection. Each scale bar is $200 \mu \mathrm{m}$. Abbreviations: ant., anterior; post., posterior; pl., platform. 


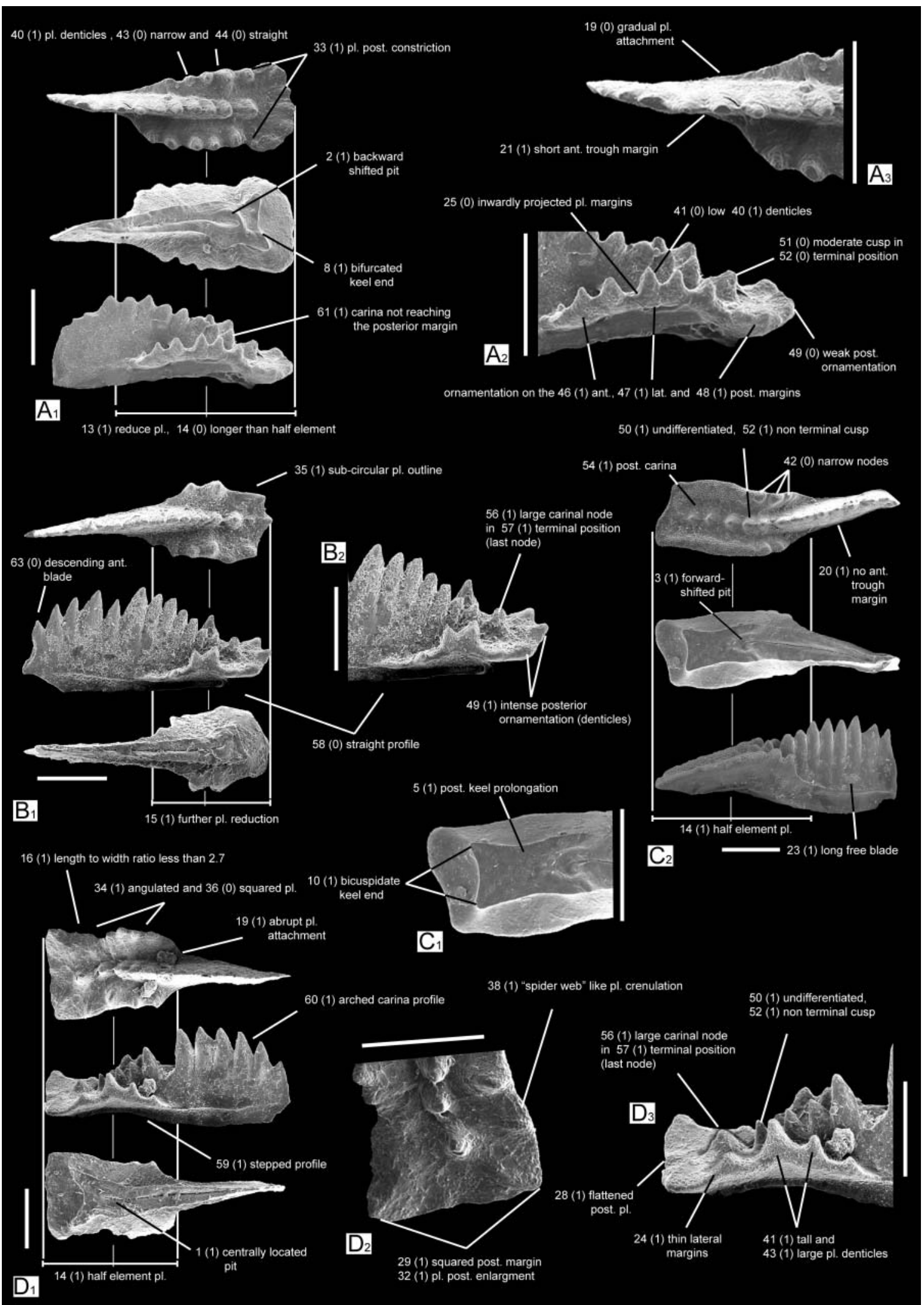

Figure 4. Representation of the morphological characters used in the cladistic analyses and of selected character states (other characters are illustrated in Fig. 3). The most representative species have been chosen to illustrate the characters. A, Carnepigondolella samueli; B, Epigondolella spatulata; $\mathbf{C}$, Metapolygnathus communisti; D, Epigondolella quadrata. All the SEM microphotographs are from specimens of the Pizzo Mondello collection. Each scale bar is $200 \mu \mathrm{m}$. Abbreviations: ant., anterior; post., posterior; pl., platform. 


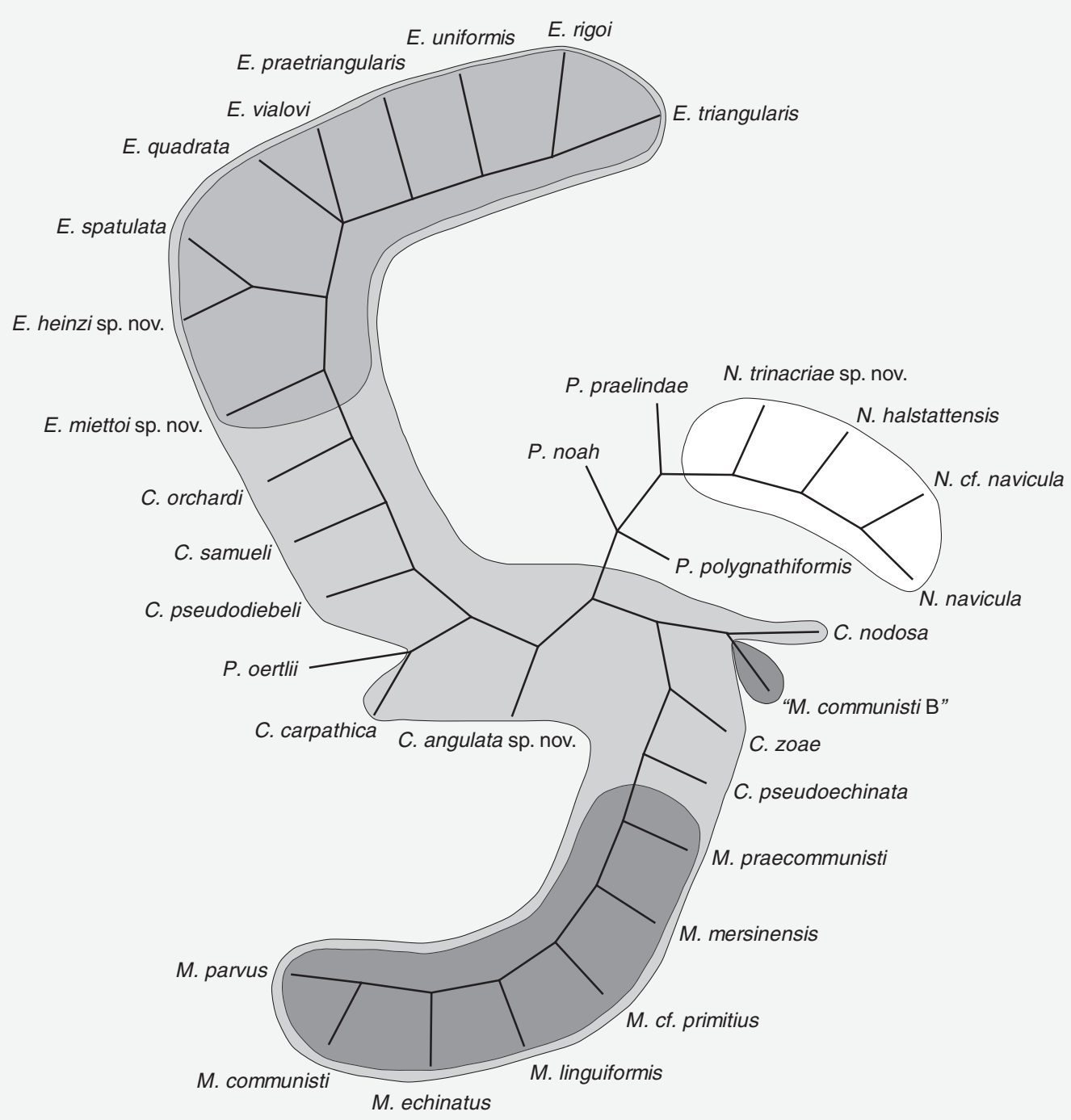

Figure 5. Unrooted diagram of outgroup and ingroup taxa analysed.

Epigondolella, Metapolygnathus and Norigondolella, while the species belonging to Carnepigondolella and Paragondolella did not form single clusters. In the text, when the terms 'lineage' and 'clade' are referred to the names Epigondolella, Metapolygnathus or Norigondolella, they mean, respectively, the most inclusive node containing that clade but excluding the other two clades, and the less inclusive node containing only the species of that genus (e.g. the 'Metapolygnathus lineage' includes the Metapolygnathus clade and all conodonts closer to it than both the Epigondolella and Norigondolella clades).

The two alternative topologies rooted on Paragondolella polygnathiformis and P. praelindae are identical in the presence of a large clade formed by Metapolygnathus, Epigondolella and the species of Carnepigondolella, but differ in the placement of the Norigondolella lineage rela- tive to the species of Paragondolella. Using P. polygnathiformis as root, a basal polytomy, formed by $P$. noah, a 'P. praelindae + Norigondolella' node and the most derived conodonts, is recovered. When P. praelindae is used as root, Norigondolella lies more basal to the polytomy formed by P. polygnathiformis, P. noah and the most derived conodonts (Fig. 6). When both P. polygnathiformis and P. praelindae are forced together as outgroups, the analysis recovers a basal polytomy including $P$. noah, the lineage including all Norigondolella species and the lineage including all other ingroup conodonts.

As previously stated, both possible outgroup species $P$. polygnathiformis and $P$. praelindae range from the early Carnian (Julian) to the late Carnian (Tuvalian), surviving the crisis triggered by the Carnian Pluvial Event. Nevertheless, P. polygnathiformis is older than P. praelindae because 
A

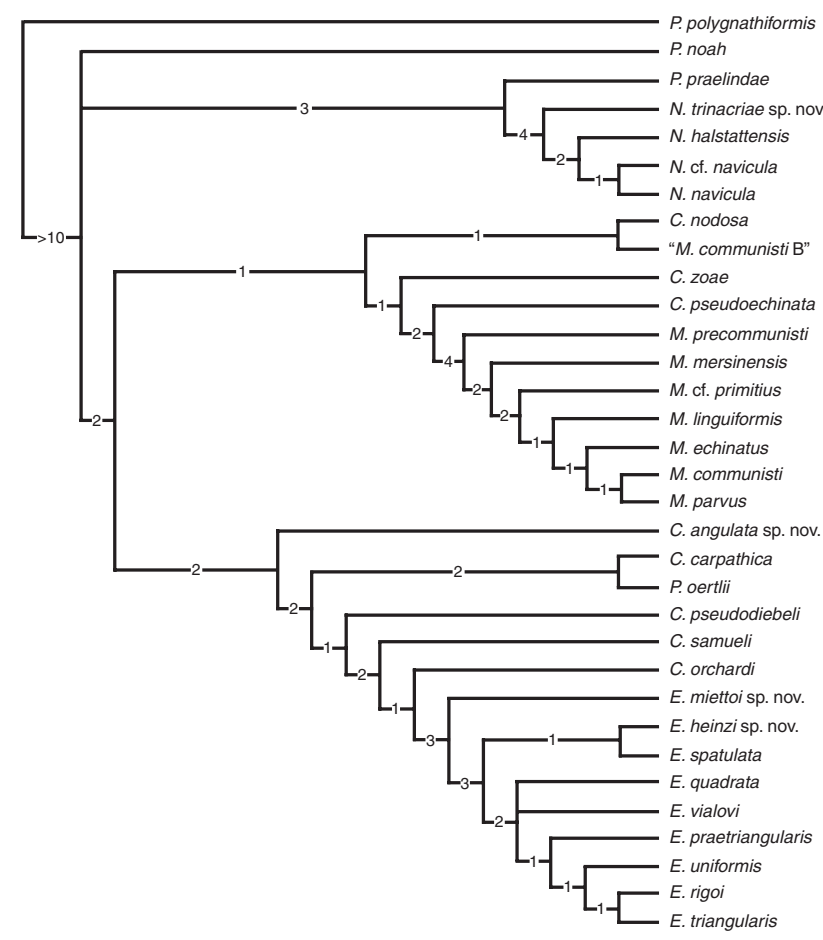

B

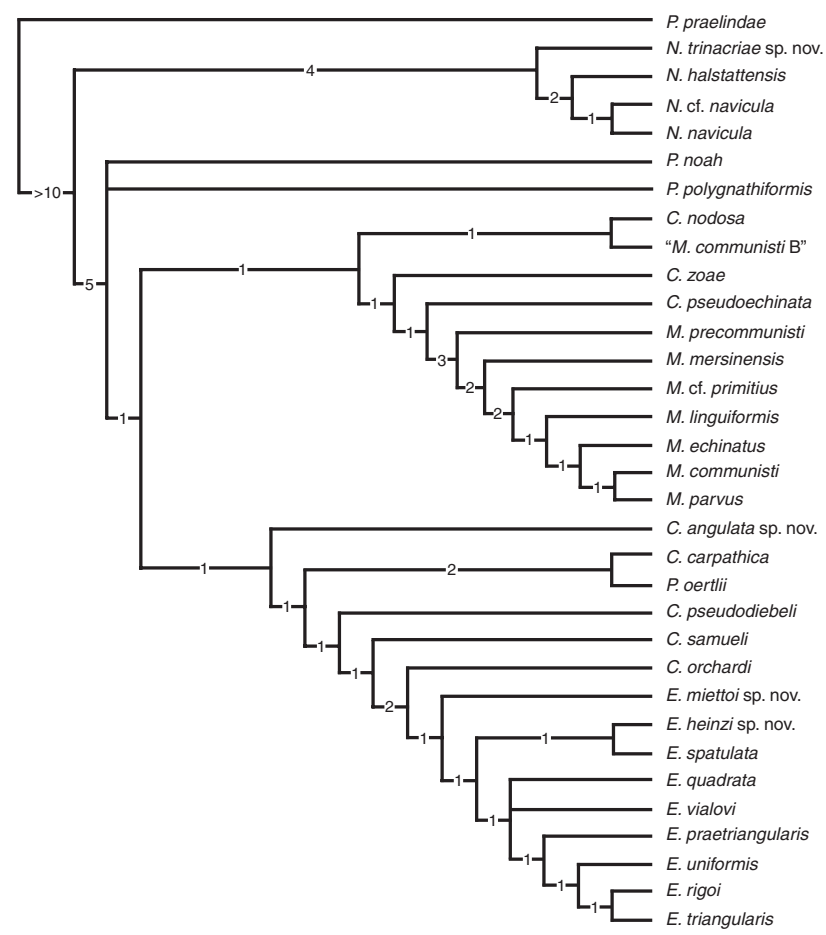

from 3867 trees, cut 0

Figure 6. Strict consensus trees (nine MPTs each) recovered using two different outgroups, after the analyses of a data matrix composed of 33 taxa and 64 characters, processed using PAUP* 4.1 (Swofford 2002) (see the text for details). A, tree rooted on Paragondolella polygnathiformis; B, tree rooted on Paragondolella praelindae. For each node, the Bremer Support (Bremer 1988) is also reported.

it first occurs at the Ladinian/Carnian boundary (Mietto et al. 2007a, b), while $P$. praelindae occurs only in the late Julian (Rigo et al. 2007). Given its younger FAD, $P$. praelindae cannot be considered an ancestor of $P$. polygnathiformis, and this species is consequently chosen as the outgroup species for the cladistic analyses. Because of the strong basal polytomy generated by using both species as outgroups, we disregarded this solution. The Strict Consensus Tree Topology of the nine MPTs rooted on P. polygnathiformis with the node enumerations is shown in Fig. 7. The list of the unambiguous synapomorphies diagnosing each node in the Strict Consensus Tree is reported in Table 2 of the Online Supplementary Material.

\section{Phylogenetic and systematic reinterpretations}

The results of the cladistic analyses lead to a reinterpretation of the phylogenetic and systematic positions of Late Triassic conodont taxa. The most parsimonious interpretation of the characters distribution rejects the hypothesis that the suprageneric taxa Paragondolella and Carnepigondolella, as currently defined, are monophyletic groups. In particular, species of the genus Paragondolella form a paraphyletic assemblage basal to the remaining lineages, supporting a previous hypothesis that this genus is the most probable common ancestor of all late Carnian-early Norian conodonts. Paragondolella praelindae, in particular, is placed at the base of the Norigondolella lineage and, thus, may be interpreted as the most direct ancestor of the genus Norigondolella. P. oertlii, in contrast, shows closest relationships with Carnepigondolella carpathica (Node 18). These two species are very similar, differing mainly in the absence of ornamentation on the $P$. oertlii anterior platform, which is otherwise characterized by very broad margins. The stratigraphical range of $P$. oertlii corresponds to the uppermost Carnian (upper Tuvalian) range of $C$. carpathica (see Fig. 8) and the two species are always present in the same sample populations. We thus interpret the broadening of the platform margins of $P$. oertlii as the result of the platform node merger characterizing $C$. carpathica, making $P$. oertlii an unornamented phenotype of $C$. carpathica.

The genus Carnepigondolella comprises a paraphyletic grade of species placed basal to the two derived genera Metapolygnathus and Epigondolella. Hence this group includes the transitional forms between the 'Paragondolella 


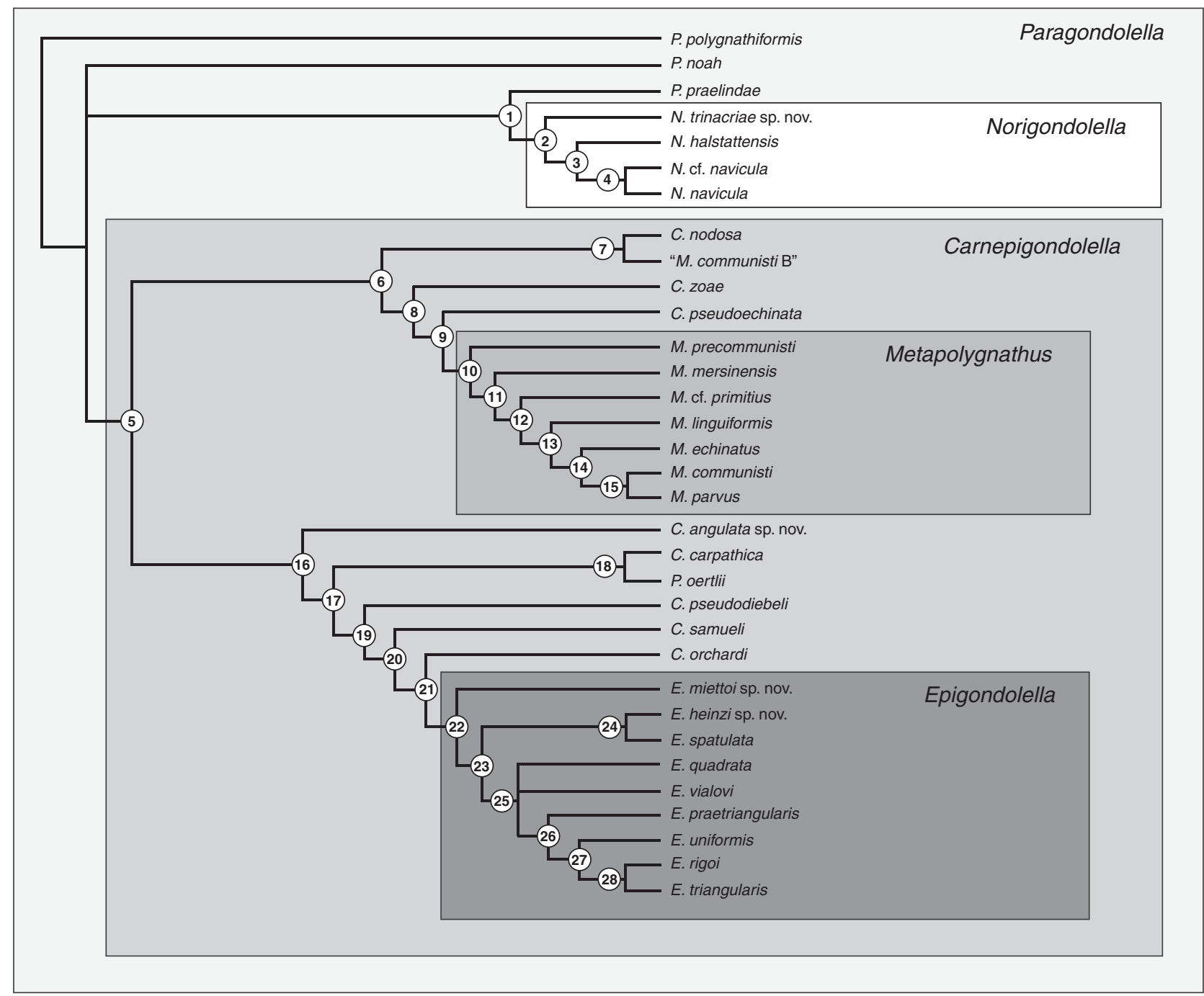

Figure 7. Strict Consensus Tree Topology of the nine MPTs rooted on Paragondolella polygnathiformis with the nodes enumeration. The unambiguous synapomorphies diagnosing each node are listed in Table 2 (Online Supplementary Material). The branches belonging to the five conodont genera considered in the cladistic analyses are evidenced, reflecting the hypotheses of relationships described in the Discussion. The monophily of the genera Norigondolella, Metapolygnathus and Epigondolella are well evident.

grade' and the genera Metapolygnathus and Epigondolella, while no relationship between Carnepigondolellae and Norigondolellae was found.

We tested the alternative hypothesis assuming that the genus Carnepigondolella is a natural (monophyletic) group, performing a phylogenetic analysis constraining its monophyly. The strict consensus tree of the 54 most parsimonious trees with this constraint showed an unresolved trichotomy formed by the three monophyletic genera Carnepigondolella, Metapolygnathus and Epigondolella. This topology is 13 steps longer than the unconstrained topology and is, therefore, a very less parsimonious interpretation of the character state distribution. We then used the Templeton test (Templeton 1983) to compare the fit of the MPTs and the alternative topology to the data. The range of probability values $(p=0.016-0.023 ; N=20)$ obtained from pair- wise comparisons indicates that the null hypothesis, which assumes that the differences between the trees in their fit to the data are no greater than expected from random sampling error, can be rejected, supporting the hypothesis of a nonmonophyletic status for Carnepigondolella.

The analyses helped to clarify also the systematic position of two problematic species: C. nodosa and 'Metapolygnathus communisti B'. C. nodosa is a very common species in the upper Carnian (Tuvalian) of the Tethyan and Neotethyan realms but, given the uncertain age of the holotype (Hayashi 1968), the origin of this species is doubtful: it could be a new Tuvalian form or a descendant of a lower Carnian (Julian) morphotype (see section on Ingroup taxa for details). The cladistic analyses revealed that $C$. nodosa is a very basal form of the Metapolygnathus lineage. This systematic position thus suggests an interpretation of this 


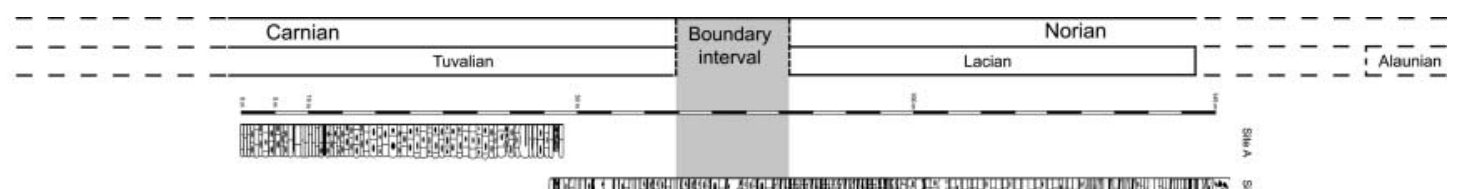

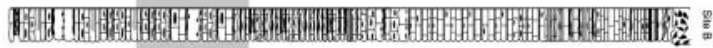

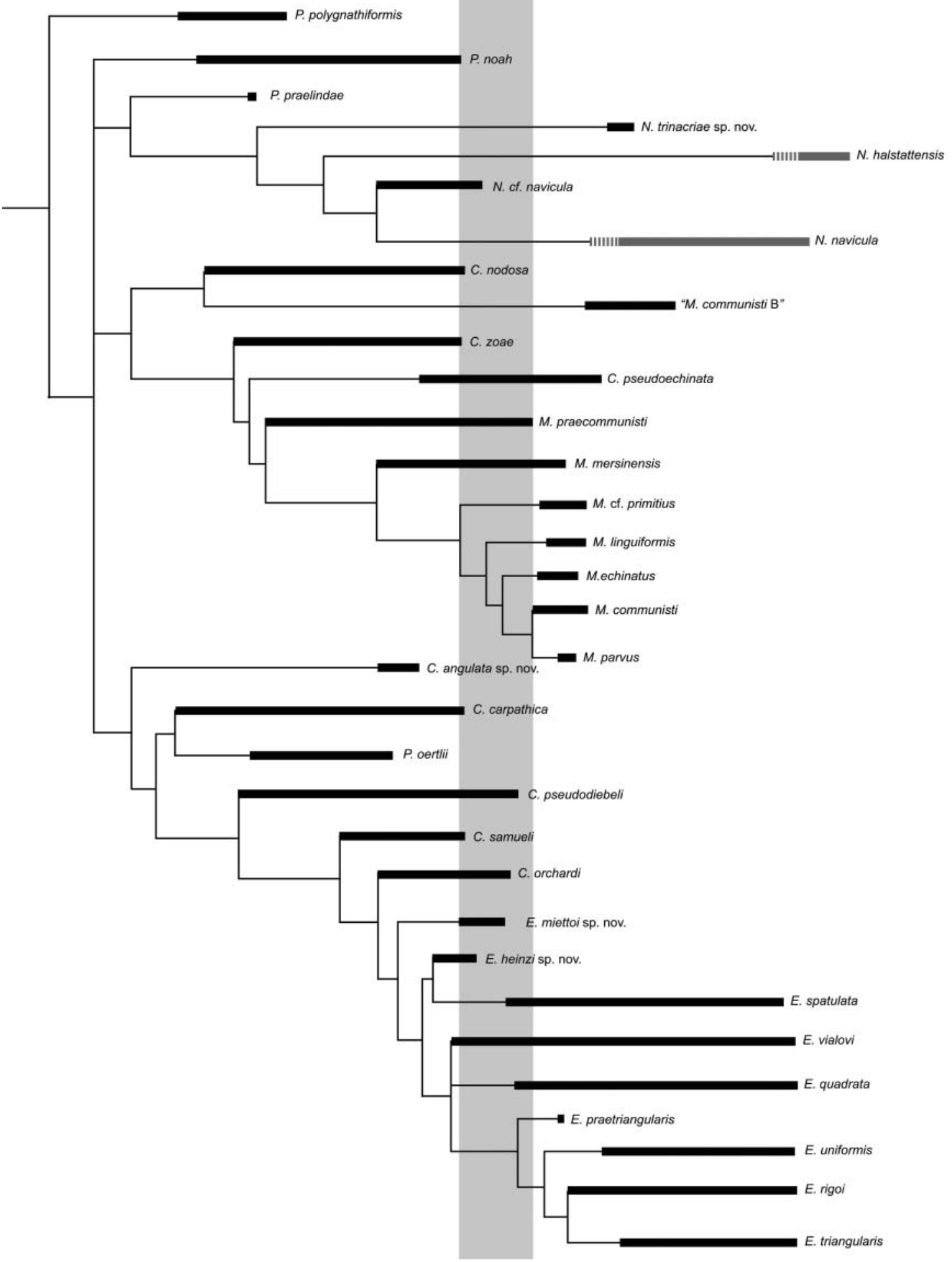

Figure 8. Stratigraphically calibrated cladogram based on the strict consensus tree topology rooted on Paragondolella polygnathiformis. The thick black bars are known stratigraphic ranges of the taxa in the Pizzo Mondello section; the grey thick lines are the Tethyan ranges of the species missing in the section deducted from the bibliography. On the left, the stratigraphical log of the Pizzo Mondello section is reported (see Mazza et al. 2010 for the samples locations). The lower Carnian (Julian) is absent in the section. 
species as relatively close to the common ancestor of the 'Metapolygnathus-Epigondolella' clade and excludes the hypothesis of any relation with the lower Carnian (Julian) morphotype.

' $M$. communisti B' is by contrast a rare taxon mostly distributed in the Tethyan and Neotethyan provinces during the Lacian (lower Norian), everywhere in a short interval above the last occurrence of $M$. communisti. It was illustrated by Krystyn (1980), but never formally established or described. Indicated by Krystyn (1980) as a possible subspecies of $M$. communisti, this species has always been quite obscure, due to its poor illustration and also its limited geographical range. Studies on rich populations of this species (Mazza et al. 2010) have suggested, however, that ' $M$. communisti B' neither belongs to the genus Metapolygnathus nor to the communisti group (according to Channell et al. 2003). The cladistic analysis confirms that ' $M$. communisti $\mathrm{B}$ ' is the sister group of $C$. nodosa (Node 7) and the two species form a basal branch of the Metapolygnathus lineage. As a consequence this species is not closely related to $M$. communisti and cannot even be considered as a species of Metapolygnathus. Given the close relationship with $C$. nodosa, we suggest that ' $M$. communisti B' may be a derivative of the former species. A new description of ' $M$. communisti B' will be presented in a forthcoming paper.

The only clades that appear monophyletic in all the most parsimonious topologies are those of Metapolygnathus, Epigondolella and Norigondolella. The Norigondolella clade does not share a close phylogenetic relationship with the derived conodonts (leading to Metapolygnathus and Epigondolella), and is interpreted as a direct descendant from a Paragondolella-grade form, perhaps $P$. praelindae (see above).

The genus Metapolygnathus was supposed to be the direct descendant of Paragondolella (Kozur 2003; Mazza et al. 2011). However, our analysis does not support a direct ancestor-descendant link between the Paragondolellagrade forms and the Metapolygnathus clade. Instead, we suggest that the genus Metapolygnathus, and M. praecommunisti in particular, may derive from $P$. noah through one (or a series of) Carnepigondolella-grade species. $M$. praecommunisti is confirmed as the possible forerunner of $M$. communisti, also as the most primitive Metapolygnathus, and thus a probable common ancestor of all other members of this clade.

In the Epigondolella lineage the evolutionary succession C. pseudodiebeli - C. orchardi - E. quadrata - E. rigoi - E. triangularis is supported by the cladistic analysis. $C$. orchardi is confirmed as the species of Carnepigondolella closest to the genus Epigondolella but, probably, not as the direct forerunner of E. quadrata. A morphotype considered as a primitive form of E. quadrata (Mazza et al. 2010), here named $E$. miettoi sp. nov., with a range limited to the Carnian/Norian boundary interval, was included in the analysis to test its relationship with the 'true' $E$. quadrata. The two forms do not share a close relationship excluding other taxa and thus are interpreted as different species, with the primitive form interpreted as the possible forerunner of E. quadrata. Another problematic issue concerning Carnian-Norian conodonts is the origin of E. spatulata, characterized by a strongly reduced and mostly sub-circular platform. The analysis supports a close relationship between $E$. heinzi sp. nov. and E. spatulata (Node 24), revealing a strict relationship between these two species. The descent of $E$. spatulata from the former (and older) species may be supposed. We note that C. pseudoechinata shares with E. spatulata a reduced platform shape and size but has weaker ornamentation. Nevertheless, since the former species is placed by our analyses in the Metapolygnathus lineage, any possible relationship between the two taxa is excluded.

\section{Evolutionary trends}

One of the aims of this work is to investigate the evolution of conodont platforms from the late Carnian to the early Norian. Evolutionary trends may be deducted from the distribution of the character state transformations in the cladogram (Online Supplementary Material, Table 2).

The genus Norigondolella forms the most basal clade of the three monophyletic groups recovered by the analysis. This clade is mainly diagnosed by having numerous plesiomorphic character states (here interpreted as evolutionary reversals) inherited by Paragondolella praelindae: lengthening of the platform, disappearance of the free blade, and lowering of the parapets and the blade (Node 1). The only apomorphic character conditions expressed by this clade are the flat loop and the thin platform margins. Further reversions characterize the most advanced Norigondolellae: shifting of the pit from a sub-terminal to a terminal position, disappearance of the platform step, loss of the geniculation point, and fusion of the nodes composing the carina. Unambiguously optimized derived states are the flattening of the posterior platform and the growth of a very large cusp, which occurs only in this genus. The large number of morphological reversions to the plesiomorphic condition makes the genus Norigondolella a very peculiar clade: it first appears in the upper Carnian ranging into the middle Norian, but its members do not follow the same evolutionary trends of the other clades, retaining instead very plesiomorphic morphotypes.

The genera Metapolygnathus and Epigondolella constitute the terminal taxa of the other two monophyletic lineages, while their basalmost members are represented by species previously referred to Carnepigondolella. It is possible to identify some evolutionary trends shared by both clades:

1. Development of platform ornamentation: both clades are identified by the development of nodes at the geniculation point and at the beginning of the platform 
(Node 5). Even if the occurrence of nodes is a common synapomorphy, the evolution of ornamentation in the two clades follows two different trends. In taxa at the base of the Metapolygnathus lineage the nodes develop also on the lateral margins (Node 6), whereas in Metapolygnathus they remain confined to the anterior platform margins (Node 10). In the Epigondolella lineage, platform ornamentation follows a clearer evolutionary trend: the nodes first evolve into low denticles and later grow also on the lateral margins (Node 19). In Epigondolella, these denticles become higher and larger (Node 22), developing successively in some terminal taxa, also on the posterior margin of the platform (Node 23).

2. Progressive forward shifting of the pit: the pit migrates from a posterior to a centrally located position in both lineages (Nodes 9 and 22). A further shifting of the pit from the central to a still more frontal position occurs in Node 14, but this characterizes only the most terminal members of the Metapolygnathus clade.

3. Gradual shortening of the platform: the platform shortens from two-thirds the length of the element to half its length (Nodes 12 and 22). A further reduction to less than half element length is also observable, but only in the most terminal taxa of the Metapolygnathus clade (Node 14). This trend is associated with a proportional lengthening of the free blade, which is longer in those taxa with a reduced platform.

4. Gradual reduction of the anterior trough margin: this feature is well developed in Paragondolellae but it becomes gradually shorter in Carnepigondolellae (Nodes 8 and 20) and disappears in both the Metapolygnathus and Epigondolella lineages (Nodes 12 and 23).

5. Cusp size and position: the reduction in cusp size is a synapomorphy common to both lineages (Nodes 10 and 23), such as its shifting from a terminal to a more inner position on the carina (Nodes 10 and 25). The shifting of the cusp is also associated with the development of accessorial nodes behind it.

6. Profile of the platform lower side: this changes from an arched to a stepped morphology in both lineages (Nodes 13 and 21). The anterior part of the element thus forms a descending step immediately in front of the pit.

Additional transformations that are identified as autapomorphies of either the Metapolygnathus or the Epigondolella clade are:

1. Gradual prolongation of the keel behind the pit is an unambiguous synapomorphy which occurs just once in the cladogram (Node 10) and characterizes only the most derived Metapolygnathus species.
2. Bifurcation of the keel end in correspondence with the pit and enlargement of the posterior platform occur only in the Epigondolella clade (Node 16) and characterize the included taxa.

3. Thinning of the platform lateral margins and flattening of the posterior platform are peculiar to the Epigondolella clade (Nodes 20 and 21). These synapomorphies occur also in Norigondolellae (Nodes 1 and 2) but are absent in metapolygnathids. In the Epigondolella clade (Node 21) flattening of the posterior platform is associated with a stretching of the platform microcrenulation (Node 21), which generates a 'spider web' pattern covering the entire platform margins.

4. Flattening of the loop characterizes the lower side morphology of the most derived Epigondolellae (Node 23).

5. Growth of a carinal node behind the cusp larger than the other carinal nodes is a synapomorphy occurring only in the most derived taxa of the Epigondolella clade (Node 25).

6. The most derived Epigondolella species share the subtriangular shape of the platform (Node 26) that is a synapomorphy not occurring in any other taxa.

\section{Cladistic analysis and conodont biostratigraphy}

Since conodonts are a very abundant fossil group in Upper Triassic successions and their biostratigraphical record is well documented, the intraspecific relationships outlined by our cladistic analysis cannot be considered in isolation from the stratigraphical distributions of these conodonts. We thus integrated the strict consensus tree with the known conodont distributions in the Pizzo Mondello section (Fig. 8). Conodont biostratigraphy is largely consistent and indicates that the phylogenetic relationships described herein match conodont bioevents (i.e. first and last occurrences), with the acquisition of derived morphologies following the chronological order that the biostratigraphy imposes. The 'transitional' morphotype of the Carnepigondolellagrade taxa is thus supported by the stratigraphical distribution of the single Carnepigondolella species, ranging from the upper Carnian to the Carnian/Norian boundary interval, when Epigondolellae and the most derived metapolygnathids first occurred. The appearance of these two taxa in the lowermost Norian thus fits with the interpretation suggested by the cladistic analysis in which they are the most derived groups.

Some discrepancies between the cladogenetic pattern (the timing of species origins inferred from their hierarchical nesting in the cladogram) and conodont biostratigraphical events (the first occurrences of species) are, however, observed amongst the taxa of the Norigondolella clade and between Carnepigondolella nodosa and 'Metapolygnathus communisti B', where the lineage between the 
last occurrence of $C$. nodosa and its supposed descendant ' $M$. communisti $\mathrm{B}$ ' is missing. Although all the other species analysed occur in both the Tethyan and Neotethyan provinces (Mazza 2010), Norigondolellae are strongly facies controlled (Kozur 2003). We also note that ' $M$. communisti B' occurs in the section with a sudden and mass appearance (Mazza et al. 2010). We suggest that the discrepancies between the cladogenetic and the biostratigraphical patterns of these taxa may be explained by migratory events from other provinces.

Sedimentological studies and geochemical analyses of stable isotopes $\left(\delta^{13} \mathrm{C}\right.$ and $\left.\delta^{18} \mathrm{O}\right)$ of the carbonate bulk fraction revealed some correlation with the proliferation of some taxa (Mazza et al. 2010). In particular, Epigondolella proliferates when seawater $\delta^{13} \mathrm{C}$ ranges between $2.1 \%$ and $2.5 \%$, while Metapolygnathus appears to be limited to environmental conditions with higher $\delta^{13} \mathrm{C}$ values $(>2.5 \%$ ). However, this influence is restricted to conodont relative abundances and proliferation, and there is no evidence of any climatic effect on platform evolution.

\section{Conclusions}

The application of cladistic analyses to late Carnian-early Norian conodont platform elements allows evolutionary trends involving the $\mathrm{P} 1$ elements to be delineated and points to possible new phylogenetic relationships among the analysed taxa:

1. Carnian Paragondolellae form a polyphyletic assemblage.

2. Carnepigondolella is a paraphyletic grade of species more derived than Paragondolella and Norigondolella but placed outside the two derived genera Metapolygnathus and Epigondolella. Species of this group represent transitional forms between Paragondolella-grade species and the genera Metapolygnathus and Epigondolella.

3. Although monophyly of the genera Paragondolella and Carnepigondolella is not supported by our phylogenetic analyses, we defer taxonomic adjustments, e.g. expanding the inclusiveness of Norigondolella, Metapolygnathus and Epigondolella in order to encompass all the species belonging to their lineages. Our conservative approach aims to maintain taxonomic continuity with published literature and to avoid the proliferation of taxonomic names defined in conflicting ways. Following our approach, the names 'Carnepigondolella' and 'Paragondolella' should not be abandoned but used to refer to two hierarchically nested grades of Late Triassic conodonts.

4. The monophyly of the Metapolygnathus, Epigondolella and Norigondolella clades is well supported in all the most parsimonious topologies. We thus suggest the following taxonomic definitions for these three genera:

- Metapolygnathus: the least inclusive clade containing all the descendants of the first conodont showing a posterior prolongation of the keel behind the pit (i.e. $M$. praecommunisti), homologous to the condition present in M. communisti (type species of the genus);

- Epigondolella: the least inclusive clade containing all the descendants of the first conodont showing a centrally located pit, a short platform and high and large denticles on the platform margins (e.g. E. miettoi sp. nov.), homologous to the condition present in $E$. quadrata and E. abneptis (type species of the genus);

- Norigondolella: the least inclusive clade containing all the descendants of the first conodont showing a terminal pit, a very large cusp, a flat posterior platform margin and no geniculation point, homologous to the conditions in $N$. navicula (the type species of the genus). The most probable direct forerunner of this genus is Paragondolella praelindae.

5. 'Metapolygnathus communisti B' is seemingly a descendant of Carnepigondolella nodosa and it definitely has no close phylogenetic relationships with $M$. communisti.

\section{Acknowledgements}

The authors are grateful to Alda Nicora (Università degli Studi di Milano) for her helpful suggestions and discussions on conodonts. Special thanks go to Associate Editor Andrew Smith (Natural History Museum, London) and the two anonymous reviewers for their valuable contributions leading to the improvement of this paper. Thanks are given to Agostino Rizzi (Università degli Studi di Milano) for technical assistance in preparation of the material and scanning electron microphotographs. Research funded was by ex-60\% (code 60A05-2288/09), Principal Investigator Manuel Rigo (University of Padova), and by MIUR PRIN (2008BEF5Z7_001), PI Marco Balini (Università degli Studi di Milano).

\section{Supplementary material}

Supplementary material can be viewed online doi:10.1080/14772019.2011.573584

\section{References}

Bateson, W. 1886. The ancestry of the Chordata. Quarterly Journal of Microscopical Science, 26, 535-571.

Bremer, K. 1988. The limits of amino acid sequence data in angiosperm phylogenetic reconstruction. Evolution, 42, 795-803. 
Burij, G. I. 1997. Triassic conodont biostratigraphy of the Sikhote-Alin. Mémoire Géologie, 30, 45-60.

Celarc, B. \& Kolar-Jurkovšek, T. 2008. The Carnian-Norian basin-platform system of the Martuljek Mountain Group (Julian Alps, Slovenia): progradation of the Dachstein carbonate platform. Geologica Carpathica, 59, 211-224.

Channell, J. E. T., Kozur, H. W., Sievers, T., Mock, R., Aubrecht, R. \& Sykora, M. 2003. Carnian-Norian biomagnetostratigraphy at Silickà Brezovà (Slovakia): correlation to other Tethyan sections and to the Newark Basin. Palaeogeography, Palaeoclimatology, Palaeoecology, 191, 65-109.

Donoghue, P. C. J. 1998. Growth and patterning in the conodont skeleton. Philosophical Transactions of the Royal Society, Series B, 353, 633-666.

Donoghue, P. C. J. 2001. Conodonts meet cladistics: recovering relationships and assessing the completeness of the conodont fossil record. Palaeontology, 44, 65-93.

Donoghue, P. C. J., Purnell, M. A., Aldridge, R. J. \& Zhang, S. 2008. The interrelationships of 'complex' conodonts (Vertebrata). Journal of Systematic Palaeontology, 6, 119-153.

Dzik, J. 1976. Remarks on the evolution of Ordovician conodonts. Acta Palaeontolologica Polonica, 21, 395-455.

Eichenberg, W. 1930. Conodonten aus dem Culm des Harzes. Paläontologische Zeitschrift, 12, 177-182.

Farris, J. S. 1977. Phylogenetic analysis under Dollo's Law. Systematic Zoology, 26, 77-88.

Farris, J. S. 1979a. On the naturalness of phylogenetic classification. Systematic Zoology, 28, 200-214.

Farris, J. S. 1979b. The information content of the phylogenetic system. Systematic Zoology, 28, 483-519.

Farris, J. S. 1980. The efficient diagnoses of the phylogenetic system. Systematic Zoology, 29, 386-401.

Farris, J. S. 1982. Outgroups and parsimony. Systematic Zoology, 31, 328-334.

Farris, J. S. 1983. The logical basis of phylogenetic analysis. Pp. 1-47 in N. I. Platnick \& V. A. Funk (eds) Advances in Cladistics, Volume 2. Proceedings of the Second Meeting of the Willi Hennig Society. Columbia University Press, New York.

Goloboff, P., Farris, J. S. \& Nixon, K. 2008. TNT: a free program for phylogenetic analysis. Cladistics, 24, 774-786.

Guaiumi, C., Nicora, A., Preto, N., Rigo, M., Balini, M., Di Stefano, P., Gullo, M., Levera, M., Mazza, M. \& Muttoni, G. 2007. New biostratigraphic data around the Carnian/Norian boundary from the Pizzo Mondello section, Sicani Mountains, Sicily. New Mexico Museum of Natural History and Science Bulletin, 41, 40-42.

Hayashi, S. 1968. The Permian conodonts in chert of the Adoyama Formation, Ashio Mountains, Central Japan. Earth Science (Chikyu Kagaku), 22(2), 63-77.

Kozur, H. 1980. Revision der Conodontenzonierung der Mittelund Obertrias des tethyalen Faunenreichs. GeologischPaläontologische Mitteilungen Innsbruck, 10(3-4), 79-172.

Kozur, H. 1989. Significance of events in conodont evolution for the Permian and Triassic stratigraphy. Courier ForschungsInstitut Senckenberg, 117, 385-408.

Kozur, H. 1990. Norigondolella n. gen., eine neue obertriassische Conodontengattung. Paläontologische Zeitschrift, 64, $125-132$

Kozur, H. 2003. Integrated ammonoid, conodont and radiolarian zonation of the Triassic. Hallesches Jahrbuch für Geowissenschaften, 25, 49-79.

Krystyn, L. 1980. Stratigraphy of the Hallstatt region. Abhandlungen der Geologishen Bundesanstalt, 35, 69-98.

Lindström, M. 1970. A suprageneric taxonomy of the conodonts. Lethaia, 3, 427-445.
Linnaeus, C. 1758. Systema naturae per regna tria naturae. 10th edition. Laurentii Salvii, Stockholm, 824 pp.

Martini, R., Zaninetti, L., Abate, B., Renda, P., Doubinger, J., Rauscher, R. \& Vrielynck, B. 1991. Sédimentologie et biostratigraphie de la formation triasique Mufara (Sicile occidentale): foraminiféres, conodontes, palynomorphes. Rivista Italiana di Paleontologia e Stratigrafia, 97(2), 131152.

Mazza, M. 2010. Carnian/Norian conodonts from the Pizzo Mondello section (Monti Sicani, Western Sicily), GSSP candidate for the base of the Norian: integrated biostratigraphy, phylogeny and stable isotope analyses Unpublished $\mathrm{PhD}$ thesis, Università degli Studi di Milano.

Mazza, M. \& Rigo, M. 2008. Taxonomy and phylomorphogenesis of the Carnian/Norian conodonts from Pizzo Mondello section (Sicani Mountains, Sicily). Berichte der Geologischen Bundesanstalt, 76, 50-52.

Mazza, M., Furin, S., Spötl, C. \& Rigo, M. 2010. Generic turnovers of Carnian/Norian conodonts: climatic control or competition? Palaeogeography, Palaeoclimatology, Palaeoecology, 290, 120-137.

Mazza, M., Rigo, M. \& Nicora, A. 2011. A new Metapolygnathus platform conodont species and its implications for Upper Carnian global correlations. Acta Palaentologica Polonica, 56, 121-131.

Mietto, P., Andretta, R., Broglio Loriga, C., Buratti, N., Cirilli, S., De Zanche, V., Furin, S., Gianolla, P., Manfrin, S., Muttoni, G., Neri, C., Nicora, A., Posenato, R., Preto, N., Rigo, M., Roghi, G. \& Spötl, C. 2007a. A candidate of the Global boundary Stratotype Section and Point for the base of the Carnian Stage (Upper Triassic). GSSP at the base of the canadensis Subzone (FAD of Daxatina) in the Prati di Stuores/Stuores Wiesen section (Southern Alps, NE Italy). Albertiana, 36, 78-97.

Mietto, P., Buratti, N., Cirilli, S., De Zanche, V., Gianolla, P., Manfrin, S., Nicora, A., Preto, N., Rigo, M. \& Roghi, G. 2007b. New constraints for the Ladinian-Carnian boundary in the Southern Alps. Suggestions for global correlations. Bulletin of the New Mexico Museum of Natural History and Science, 41, 275-281.

Moix, P., Kozur, H. W., Stampfli, G. M. \& Mostler, H. 2007. New paleontological, biostratigraphic and paleogeographic results from the Triassic of the Mersin melange, SE Turkey. Bulletin of the New Mexico Museum of Natural History and Science, 41, 282-311.

Mosher, L. C. 1968. Triassic conodonts from western North America and Europe and their correlation. Journal of Paleontology, 42, 895-946.

Muttoni, G., Kent, D. V., Di Stefano, P., Gullo, M., Nicora, A., Tait, J. \& Lowrie, W. 2001. Magnetostratigraphy and biostratigraphy of the Carnian/Norian boundary interval from the Pizzo Mondello section (Sicani Mountains, Sicily). Palaeogeography, Palaeoclimatology, Palaeoecology, 166, 383-399.

Muttoni, G., Kent, D. V., Olsen, P. E., Di Stefano, P., Lowrie, W., Bernasconi, S. M. \& Hernández, F. M. 2004. Tethyan magnetostratigraphy from Pizzo Mondello (Sicily) and correlation to the Late Triassic Newark astrochronological polarity time scale. Geological Society of America Bulletin, 116, 1043-1058.

Muttoni, G., Meço, S. \& Getani, M. 2005. Magnetostratigraphy and biostratigraphy of the Late Triassic Guri Zi section, Albania: constraint on the age of the Carnian-Norian boundary. Rivista Italiana di Paleontologia e Stratatigrafia, 111(2), 233-245.

Nicora, A., Balini, M., Bellanca, A., Bertinelli, A., Bowring, S. A., Di Stefano, P., Dumitrica, P., Guaiumi, C., Gullo, M., 
Hungerbuehler, A., Levera, M., Mazza, M., McRoberts, C. A., Muttoni, G., Preto, N. \& Rigo, M. 2007. The Carnian/Norian boundary interval at Pizzo Mondello (Sicani Mountains, Sicily) and its bearing for the definition of the GSSP of the Norian Stage. Albertiana, 36, 102-129.

Noyan, O. \& Kozur, H. 2007. Revision of the late Carnianearly Norian conodonts from the Stefanion section (Argolis, Greece) and their paleobiogeographic implications. Neues Jahrbuch für Geologie und Paläontologie Abhandlungen, 245(2), 159-178.

Orchard, M. J. 1983. Epigondolella populations and their phylogeny and zonation in the Upper Triassic. Fossils and Strata, 15, 177-192.

Orchard, M. J. 1991a. Late Triassic conodont biochronology and biostratigraphy of the Kunga Group, Queen Charlotte Islands, British Columbia. Pp. 173-193 in G. W. Woodsworth (ed.) Evolution and Hydrocarbon Potential of the Queen Charlotte Basin, British Columbia. Geological Survey of Canada, Paper 90-10.

Orchard, M. J. 1991b. Upper Triassic conodont biochronology and new index species from the Canadian Cordillera. Pp. 299-335 in M. J. Orchard \& A.D. McCracken (eds) Ordovician to Triassic conodont paleontology of the Canadian Cordillera. Geological Survey of Canada, Bulletin 417.

Orchard, M. J. 2005. Multielement conodont apparatuses of Triassic Gondolelloidea. Special Papers in Palaeontology, 73, 73-101.

Orchard, M. J. 2007. A proposed Carnian-Norian Boundary GSSP at Black Bear Ridge, northeast British Columbia, and a new conodont framework for the boundary interval. Albertiana, 36, 130-141.

Orchard, M. J. \& Rieber, H. 1999. Multielement Neogondolella (Conodonta, upper Permian - middle Triassic). Bollettino della Societá Paleontologica Italiana, 37, 475-488.

Pálfy, J., Demény, A., Haas, J., Carter, E. S., Görög, Á., Halász, D., Oravecz-Scheffer, A., Hetényi, M., Márton, E., Orchard, M. J., Ozsvárt, P., Vetó, I. \& Zajzon, N. 2007. Triassic-Jurassic boundary events inferred from integrated stratigraphy of the Csóvár section, Hungary. Palaeogeography, Palaeoclimatology, Palaeoecology, 244, 11-33.

Preto, N., Kustatscher, E. \& Wignall, P. B. 2010. Triassic climates - State of the art and perspectives. Palaeogeography, Palaeoclimatology, Palaeoecology, 290, 1-10.

Purnell, M. A., Donoghue, P. C. J. \& Aldridge, R. J. 2000. Orientation and anatomical notation in conodonts. Journal of Paleontology, 74, 113-122.

Rieber, H. 1980. Ein Conodonten-cluster aus der Grenzbitumenzone (Mittlere Trias) des Monte San Giorgio (Kt. Tessin/Schweiz). Annalen des Naturhistorischen Museums in Wien, Serie A, 83, 265-274

Rigo, M. 2006. Investigations on Upper Triassic pectiniforms conodonts. Unpublished $\mathrm{PhD}$ thesis, Università degli Studi di Padova.

Rigo, M. \& Joachimski, M. 2010. Palaeoecology of Late Triassic conodonts: Constraints from oxygen isotopes in biogenic apatite. Acta Palaeontologica Polonica, 55, 471-478.

Rigo, M., Preto, N., Roghi, G., Tateo, F. \& Mietto, P. 2007. A CCD rise in the Carnian (Upper Triassic) of western Tethys, deep-water equivalent of the Carnian Pluvial Event. Palaeogeography, Palaeoclimatology, Palaeoecology, 246, 188-205.

Sereno, P. C. 2007. Logical basis for morphological characters in phylogenetics. Cladistics, 23, 565-587.

Simms, M. J. \& Ruffell, A. H. 1989. Synchroneity of climatic change and extinctions in the Late Triassic. Geology, 17, 265-268.

Simms, M. J., Ruffell, A. H. \& Johnson, A. L. A. 1995. Biotic and climatic changes in the Carnian (Triassic) of Europe and adjacent areas. Pp. 352-365 in N. C. Fraser \& H. D. Sues (eds) In the Shadow of the Dinosaurs. Early Mesozoic tetrapods. Cambridge University Press, Cambridge.

Sweet, W. C. 1981. Morphology and composition of elements. Pp. W5-W67 in R.A. Robison (ed.) Treatise on invertebrate paleontology. Part W. Miscellanea, supplement 2, Conodonta. Geological Society of America and the University of Kansas, Boulder and Lawrence.

Swofford, D. L. 2002. PAUP* : Phylogenetic Analysis Using Parsimony (and other methods). 4.0 beta10, Programme and documentation. Sinauer, Sunderland, MA.

Templeton, A. R. 1983. Convergent evolution and nonparametric inferences from restriction data and DNA sequences. Pp. 151-179 in B. S. Weir (ed.) Statistical Analysis of DNA Sequence Data. Dekker, New York.

Wickström, L. M. \& Donoghue, P. C. J. 2005. Cladograms, phylogenies and the veracity of the conodont fossil record. Special Papers in Palaeontology, 73, 185-218.

Zhang, S. \& Barnes, C. R. 2004. The post-mass extinction bioevents, cladistics and response to glacio-eustasy of conodonts across and after the Ordovician-Silurian boundary, Anticosti Basin, Quebec. Pp. 73-104 in A. Beaudoin (ed.) The Micropalaeontology of Boundaries. The Geological Society, London.

\section{Appendix: Systematic palaeontology}

A full description and diagnosis of the four new species recognized in the Pizzo Mondello section is here given. See Mazza et al. (2010) for the stratigraphical position of the conodont samples cited.

Phylum Chordata Bateson, 1886

Subphylum Vertebrata Linnaeus, 1758

Class Conodonta Eichenberg, 1930

Order Ozarkodinida Dzik, 1976

Family Gondolellidea Lindström, 1970

Genus Carnepigondolella Kozur, 2003

Carnepigondolella angulata sp. nov.

(Fig. 9A, B)

Holotype. The specimen illustrated in Fig. 9A, 10473, in the Dipartimento di Scienze della Terra "Ardito Desio", Università degli Studi di Milano.

Derivation of name. For the strongly angulated outline of the lateral profile.

Diagnosis. Characterized by a platform with a strongly arched profile and the anterior part of the element downwardly bent. The blade is low and descends very gradually towards the cusp. The long and slender platform extends for three-quarters of the element; it has thick and parallel margins and bears low and rounded nodes on the anterior part. The pit is placed in the posterior third of the element but it is never subterminal. The keel end is bifurcated.

Material. 40 specimens from the Pizzo Mondello section (Monti Sicani, Western Sicily, Italy), a succession of white 


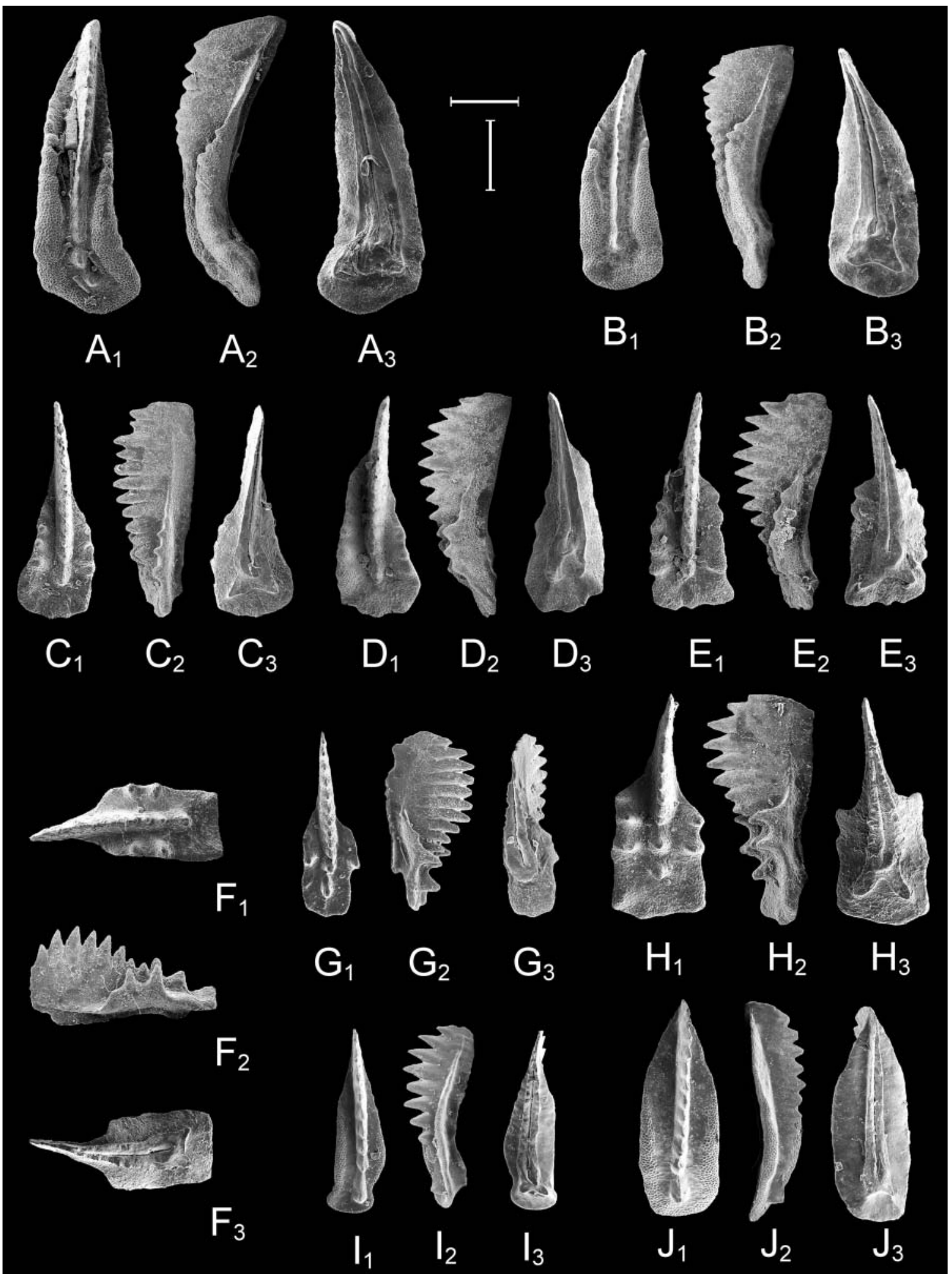

Figure 9. SEM microphotographs of the new species described. All the specimens are from the Pizzo Mondello section. A, B, Carnepigondolella angulata sp. nov.: A, holotype, mature growth stage (sample FNP52); B, morphotype with a less expanded posterior platform, mature growth stage (sample FNP53a). C-E, Epigondolella heinzi sp. nov.: C, holotype, mature growth stage (sample NA27); D, paratype, extremely mature growth stage (sample NA27); E, more squared morphotype, mature growth stage (sample NA25). F-H, Epigondolella miettoi sp. nov.: F, holotype, mature growth stage (sample FNP88a); G, sub-mature growth stage (sample NA30); H, paratype, mature growth stage (sample FNP88a). I, J, Norigondolella trinacriae sp. nov.: I, juvenile growth stage (sample NA43); J, holotype, mature growth stage (sample NA43). See Mazza et al. (2010, fig. 2) for the position of samples in the stratigraphic log. For each specimen all the three views are provided: $1=$ upper view; $2=$ lateral view; $3=$ lower view. Scale bars are $200 \mu \mathrm{m}$; all the specimens are at the same scale. 
micritic calcilutite with black-brown cherty nodules, named Calcari con Selce. The holotype is from bed FNP52.

Occurrence. Uppermost Tuvalian (upper Carnian) in the Sicano Basin (Neotethys).

Description. The profile of this species is very characteristic. It is strongly arched in the posterior third and the anterior part is very bent downwards. The blade is not very high anteriorly but stays always quite low above the platform. The platform is long and very slender and it extends for almost the entire length of the element, leaving a free blade of only 1-2 denticles. The posterior end of the platform is rounded and it may show an enlargement confined only to the very terminal portion of the platform. The platform margins are thick and parallel, and provided with low and rounded nodes occurring only at the beginning of the platform. The cusp is the last node of the carina and it is undifferentiated in size. In the most adult growth stage a very small accessorial node follows the main denticle. The anterior trough margin is reduced. The pit lies in the posterior half of the platform but it is never terminal. The keel end is bifurcated and never posteriorly prolonged. The carina is long and composed of tiny nodes. No steps occur at the geniculation point. The frontal termination of the blade ends abruptly giving to it a truncated appearance.

Remarks. C. carpathica has a larger platform with a squared posterior margin, a less arched profile and a higher blade. C. nodosa has larger nodes which occur also on the lateral platform margins, a higher blade and the keel termination is never bifurcated.

\section{Genus Epigondolella Mosher, 1968 Epigondolella heinzi sp. nov.} (Fig. 9C-E)

Holotype. The specimen illustrated in Fig. 9C, 10474 in the Dipartimento di Scienze della Terra "Ardito Desio", Università degli Studi di Milano. It comes from sample NA27.

Derivation of name. In honour of Dr Heinz Kozur for his extraordinary contribution to the knowledge of Triassic conodonts.

Diagnosis. A primitive Epigondolella with a short platform (half element) with sharp but low denticles on the lateral thin platform margins. The posterior platform is typically enlarged and ornamented with nodes. The pit is centrally located, or shifted slightly posteriorly, and it is terminal to the keel end. The keel termination is always bifurcated. The blade is high and it descends slowly towards the cusp. The free blade is long.

Material. 63 specimens from the Pizzo Mondello section.
Occurrence. Uppermost Tuvalian (upper Carnian) to the lowermost Lacian (lower Norian) in the Sicano Basin (Neotethys).

Description. This species is characterized by a short platform (half element) with thin margins. Three or four sharp and low denticles occur on the lateral margins and four low nodes on the posterior. The platform rapidly tapers anteriorly, while posteriorly it is typically enlarged. The posterior margin, usually asymmetrical on one side, is rounded, even if in some specimens it may be slightly squared. The anterior trough margin is reduced while the free blade is long, being composed of 5-6 denticles. The cusp, which is the last node of the carina, is discrete in size and isolated. The pit is centrally located or slightly backwardly shifted, and it is terminal to the keel end. The keel termination is always bifurcated. The basal cavity is surrounded by a prominent loop. The blade is high and it descends slowly anteriorly and posteriorly towards the cusp. The denticles of the blade are highly fused but the tips are separated.

Remarks. This new species is a primitive Epigondolella: the platform is short, the pit is almost central but the platform denticles are still low. In the early juvenile growth stages the posterior expansion is already present, but the platform is smaller and the margins are very thin. In the super-adult growth stages instead, the platform margins are strongly thickened and the platform denticles have the tendency to coalesce together. E. heinzi sp. nov. is similar to Carnepigondolella sp. nov. N of Orchard (2007) and to C. pseudoechinata, but it differs from both in its more expanded posterior end, more denticulate platform margins, the bifurcated keel end and the more centrally located pit.

The new species shares the same node as E. spatulata in the strict consensus tree. The two species have in fact the same reduced platform, the rich ornamentation (low denticles in E. heinzi and high denticles in E. spatulata) developed on all the platform margins, the centrally located pit and the blade profile. It is thus very probable that the two species are phylogenetically related and, given their stratigraphical distributions (see Fig. 8), E. heinzi is seemingly the forerunner of $E$. spatulata.

Epigondolella miettoi sp. nov.

(Fig. 9F-H)

1980 Epigondolella primitia Krystyn: pl. 13, fig. 8.

1983 Epigondolella abneptis subsp. A Orchard: 181, fig. 4P (only).

1997 Metapolygnathus primitia Burij: 60, pl. 3, figs 1-3.

2003 Epigondolella abneptis Kozur in Channell et al.: 100, pl. A2, figs 16, 17, 26.

2005 Metapolygnathus nodosus Muttoni et al.: 238, pl. 2, fig. 12.

2007 Epigondolella quadrata Nicora et al.: 121, pl. 3, fig. $8^{\circ}, \mathrm{b}$. 
2007 Epigondolella quadrata Noyan \& Kozur: 165, fig. 4.1-4.4, ?4.6, 4.7.

2010 Epigondolella quadrata Mazza in Mazza et al.: 134, pl. 2, fig. 2.

Holotype. The specimen illustrated in Fig. 9F, 10475 at the Dipartimento di Scienze della Terra "Ardito Desio", Università degli Studi di Milano. It comes from sample FNP88a.

Derivation of name. In honour of Prof. Paolo Mietto, for his outstanding studies on the Triassic system.

Diagnosis. An Epigondolella with a short platform (about half element), characterized by thin and parallel lateral margins provided with large and high denticles. The posterior platform is flat and typically squared. The anterior blade is high and descends slowly towards the cusp with an arched profile. The cusp is the last carinal node, and it is large, posteriorly inclined and separated from the other nodes. The pit is centrally located, or placed slightly behind the middle of the platform, and terminal to the keel. The keel end is always bifurcated.

Material. 44 specimens from the Pizzo Mondello section.

Occurrence. Uppermost Tuvalian (upper Carnian) to lowermost Lacian (lower Norian) of the Neotethys and Northern Tethys.

Description. This species has a quite short platform, which extends from half to two-thirds of the entire element, characterized by thin and parallel lateral margins covered by a 'spider web'-like microcrenulation. Very typical of this species is the morphology of the posterior platform, which is squared, flat, with posterolaterally pointed corners and it lacks any constriction or posterior enlargement. This morphology gives the entire platform a typical subrectangular outline. The anterior trough margin is present but reduced, leaving a short free blade of 3-4 denticles. The lateral margins of the platform usually bear two high and large denticles on the inner side and three on the outer side. The carina is composed of two low and fused nodes, which are followed by two further wide, separated nodes on the posterior platform. The cusp is the last node of this series of carinal nodes; it is larger in size than the other nodes and strongly backwardly inclined.

The pit is narrow and surrounded by a prominent loop; it lies in the middle of the platform or slightly behind it. The keel termination is always bifurcated in correspondence to the pit. The lower profile of the element is stepped and the corners of the posterior margin are slightly upturned. The blade is high in its anterior part, with lower denticles at its frontal termination and it decreases gradually into the low carina with an arched profile. A low step may occur at the geniculation point.

Remarks. E. miettoi sp. nov. is here interpreted as the most probable direct forerunner of E. quadrata. Kozur (2003) identified Carnepigondolella orchardi as the immediate forerunner of $E$. quadrata, proposing the series $C$. pseudodiebeli-C. orchardi-E. quadrata as a possible phylogenetic lineage. This lineage is supported also by the cladistic analyses, but we suggest inserting $E$. miettoi between C. orchardi and E. quadrata in the evolutionary sequence, since this species has evident transitional characters between these two taxa. The transitional nature of E. miettoi has been noted before. Mazza et al. (2010) considered this species as a primitive form of E. quadrata, in which the platform is not as reduced, a short anterior trough margin is still present and the pit is not completely centrally located. Furthermore, the two forms seemed to have the same large accessorial node behind the cusp in the centre of the posterior platform, which is a very diagnostic character of E. quadrata. More detailed observations revealed instead that the last carinal denticle of E. mietto is strongly backwardly inclined and, thus, its attachment on the platform falls in correspondence to the pit. This is a substantial difference between the two forms because in E. miettoi sp. nov. this node becomes the cusp and not an accessorial carinal node as in true E. quadrata. In the more advanced forms of E. miettoi, closer to E. quadrata, an accessorial node on the posterior platform may occur, but it is always smaller than the cusp. The difference between the two forms is confirmed also by the cladistic analyses, which place the two Epigondolellae in well-separated nodes of the cladogram, thus justifying the institution of E. miettoi.

This new species is similar to $C$. orchardi, but it differs in the sub-rectangular platform outline, shorter anterior trough margin, larger platform denticles, more centrally located pit and absence of the posterior constriction.

Genus Norigondolella Kozur, 1990 Norigondolella trinacriae sp. nov. (Fig. 9I-J)

2010 Norigondolella cf. navicula Mazza in Mazza et al.: 135 , pl. 3 , figs 2,3 .

Holotype. The specimen illustrated in Fig. 9J, 10476 in the Dipartimento di Scienze della Terra "Ardito Desio", Università degli Studi di Milano. It comes from bed NA43a.

Derivation of name. From the Ancient Greek name of Sicily (Trinacria), where this species was discovered.

Diagnosis. A Norigondolella species with a broad platform extending for all the length of the element. The platform margins have low parapets and they are thin and unornamented, except for an intense microcrenulation 
developed on their surface. The pit is narrow and subterminal to the platform. The keel termination is usually squared or it may be slightly bifurcated. The blade is high and it descends very gradually into a low carina. The cusp is terminal, it is very large in size and it is posteriorly inclined.

Material. 31 specimens from the Pizzo Mondello section.

Occurrence. Lower Lacian (Lower Norian) in the Sicano Basin (Neotethys).

Description. This species is characterized by a broad platform with low parapets extending for all the length of the element, with no free blade. The posterior and lateral platform margins are thick but become progressively thinner towards the anterior third of the element, where they are more similar to an anterior trough margin rather than to a real platform. Platform margins bear no ornamentation, except for an intense microcrenulation. The posterior end of the platform is rounded. The cusp is the last node of the carina, is bigger in size with respect to the preced- ing carinal nodes and it is posteriorly inclined. The pit is narrow and sub-terminal, being completely terminal to the posterior platform end only in juvenile specimens, while in adults it is slightly anteriorly shifted. The keel termination is square, or it may be slightly bifurcated in the most adult growth stage forms. The basal furrow is large. The element is arched in correspondence to the pit. The blade is high anteriorly, with lower denticles at its frontal termination, and it descends very gradually into a low carina.

Remarks. This species has the typical lower Norian stratigraphical occurrence of all the other Norigondolellae throughout the Tethys: just above the LAD of Metapolygnathus communisti (Channell et al. 2003; Kozur 2003) and together with the $\mathrm{FO}$ of ' $M$. communisti $\mathrm{B}$ '. It possesses all the typical characters of the genus, except for the morphology of its lower side, which is rather unusual for a Norigondolella, being characterized by a slightly anteriorly shifted pit and a squared or bifurcated keel end. Because of the peculiarity of its lower side, this Norigondolella is considered as a new species, even though its occurrence in other Tethyan provinces has yet to be proved. 
Data matrix used in the cladistic analysis. The letter $\mathrm{P}$ is for $(01)$ and indicates a polymorphic character. See the text for the characters definition.

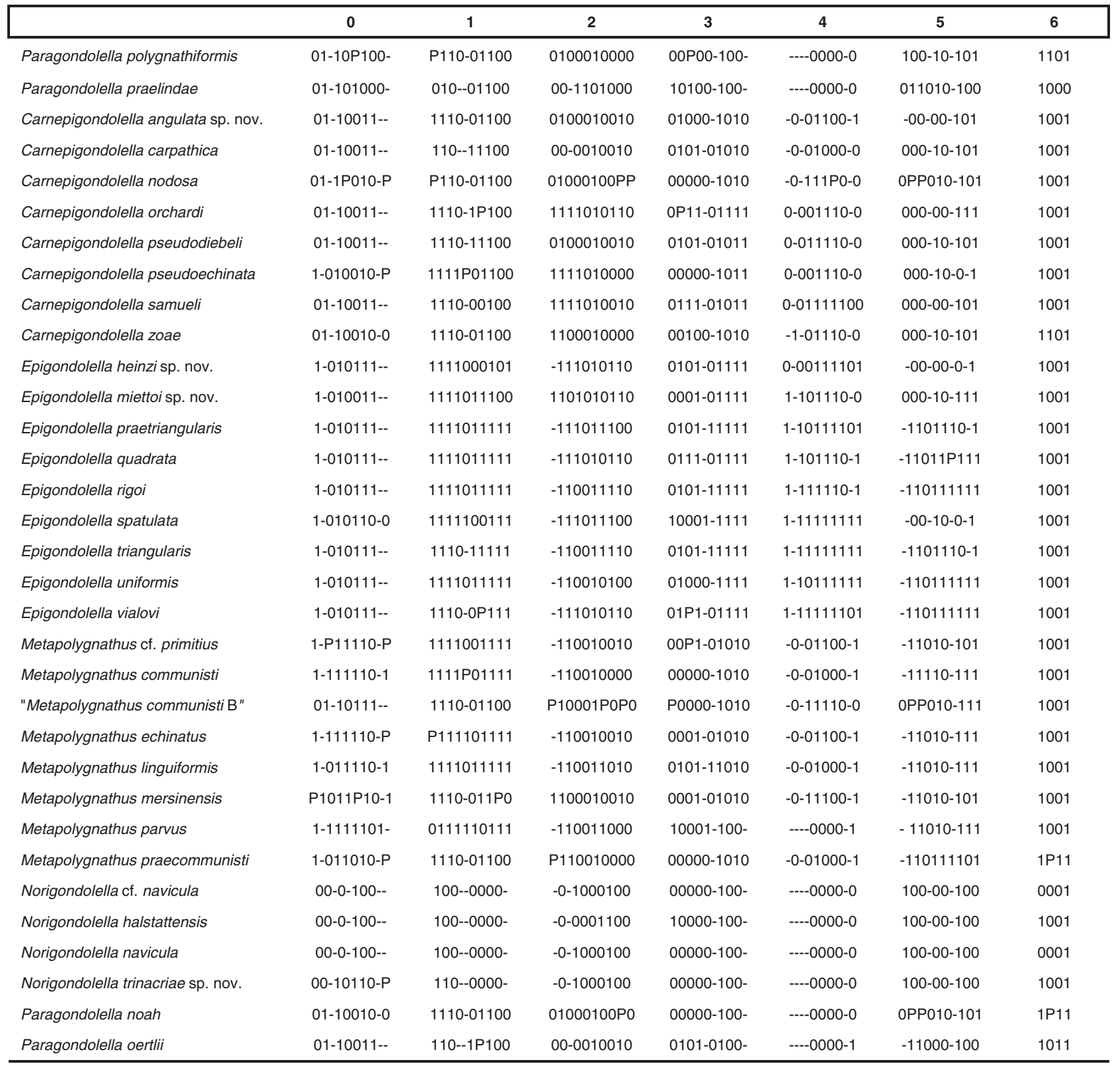


List of the unambiguous synapomorphies diagnosing each node in the Strict Consensus Tree. The node enumeration follows Fig. 7.

\begin{tabular}{|c|c|c|}
\hline Node & Included taxa & Unambiguous synapomorphyes \\
\hline 1 & $\begin{array}{l}(P . \text { praelindae }+(N . \text { trinacriae sp. nov. }+(N . \text { halstattensis }+(N . \text { navicula }+N . \text { cf. } \\
\text { navicula }))))\end{array}$ & $\begin{array}{l}\text { Char. } 6: 0 \rightarrow 1 \text {; Char. 13: } 1 \rightarrow 0 \text {; Char. 22: } 1 \rightarrow 0 \text {; } \\
\text { Char. } 24: 0 \rightarrow 1 \text {; Char. } 26: 1 \rightarrow 0 \text {; Char. } 60: 1 \rightarrow 0 \text {. }\end{array}$ \\
\hline 2 & $\begin{array}{l}\text { Norigondolella: }(N . \text { trinacriae sp. nov. }+(N . \text { halstattensis }+(N . \text { navicula }+N . \text { cf. } \\
\text { navicula })) \text { ) }\end{array}$ & $\begin{array}{l}\text { Char. } 2: 1 \rightarrow 0 \text {; Char. } 17: 1 \rightarrow 0 \text {; Char. } 18: 1 \rightarrow 0 \\
\text { Char. } 28: 0 \rightarrow 1 ; \text { Char. } 51: 0 \rightarrow 1 ; \text { Char. } 55: 1 \rightarrow 0 .\end{array}$ \\
\hline 3 & $(N$. halstattensis $+(N$. navicula $+N$. cf. navicula $))$ & Char $4: 1 \rightarrow 0$; Char. $12: 1 \rightarrow 0$ \\
\hline 4 & (N. navicula $+N$. cf. navicula ) & Char. $61: 1 \rightarrow 0$. \\
\hline 5 & 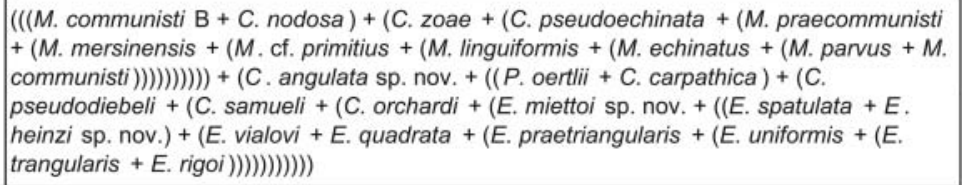 & Char. $39: 0 \rightarrow 1$; Char. $45: 0 \rightarrow 1$; Char. $46: 0 \rightarrow 1$. \\
\hline 6 & $\begin{array}{l}((M . \text { communisti B + C. nodosa })+(C . \text { zoae }+(\text { C. pseudoechinata }+(M . \text { praecommunisti } \\
+(M . \text { mersinensis }+(M . \text { cf. primitius }+(M . \text { linguiformis }+(M . \text { echinatus }+(M . \text { parvus }+M \text {. } \\
\text { communist }))))))))\end{array}$ & Char. $47: 0 \rightarrow 1$ \\
\hline 7 & (M. communisti B + C. nodosa ) & Char. $44: 0 \rightarrow 1$ \\
\hline 8 & $\begin{array}{l}(\text { C. zoae }+(\text { C. pseudoechinata }+(M . \text { praecommunisti }+(M . \text { mersinensis }+(M . \text { cf. } \\
\text { primitius }+(M . \text { linguiformis }+(M . \text { echinatus }+(M . \text { parvus }+M . \text { communisti })))))))\end{array}$ & Char. $21: 0 \rightarrow 1$ \\
\hline 9 & $\begin{array}{l}(\text { C. pseudoechinata }+(M . \text { praecommunist }+(M . \text { mersinensis }+(M . \text { cf. primitius }+(M . \\
\text { linguiformis }+(M . \text { echinatus }+(M . \text { parvus }+M . \text { communist }))))))\end{array}$ & Char. $1: 0 \rightarrow 1$; Char. $23: 0 \rightarrow 1$ \\
\hline 10 & $\begin{array}{l}\text { Metapolygnathus: }((M . \text { praecommunisti }+(M . \text { mersinensis }+(M . \text { cf. primitius }+(M . \\
\text { linguiformis }+(M . \text { echinatus }+(M \text {. parvus }+M . \text { communisti })))))\end{array}$ & $\begin{array}{l}\text { Char. } 5: 0 \rightarrow 1 ; \text { Char. } 47: 1 \rightarrow 0 \text {; Char. } 50: 0 \rightarrow 1 \\
\text { Char. } 52: 0 \rightarrow 1 ; \text { Char. } 53: 0 \rightarrow 1\end{array}$ \\
\hline 11 & $\begin{array}{l}(M . \text { mersinensis }+(M . \text { cf. primitius }+(M . \text { linguiformis }+(M . \text { echinatus }+(M . \text { parvus }+M \text {. } \\
\text { communisti }))))\end{array}$ & Char. 29: $0 \rightarrow 1$; Char. $34: 0 \rightarrow 1$ \\
\hline 12 & $(M$ cf. primitius $+(M$. linguiformis $+(M$. echinatus $+(M$. parvus $+M$. communist $i)))$ & Char. $14: 0 \rightarrow 1$; Char. $20: 0 \rightarrow 1$ \\
\hline 13 & $(M$. linguiformis $+(M$. echinatus $+(M$. parvus $+M$. communist $i)))$ & Char. $59: 0 \rightarrow 1$ \\
\hline 14 & $(M$. echinatus $+(M$. parvus $+M$. communist $i))$ & Char. $3: 0 \rightarrow 1 ;$ Char. $15: 0 \rightarrow 1$ \\
\hline 15 & (M. parvus + M. communisti) & Char. 29: $1 \rightarrow 0$; Char. $34: 1 \rightarrow 0$. \\
\hline 16 & $\begin{array}{l}(\text { C. angulata sp. nov. }+((P . \text { oertlii }+ \text { C. carpathica })+(\text { C. pseudodiebeli }+(\text { C. samueli }+(C . \\
\text { orchardi }+(E . \text { miettoi sp. nov. }+((E . \text { spatulata }+E . \text { heinzi sp. nov. })+(\text { E. vialovi }+ \\
\text { E. quadrata }+(\text { E. praetriangularis }+(\text { E. uniformis }+(\text { E. trangularis }+ \text { E. rigoi }))))))))))\end{array}$ & Char. $8: 0 \rightarrow 1$; Char. $29: 0 \rightarrow 1$; Char. $32: 0 \rightarrow 1$ \\
\hline 17 & $\begin{array}{l}((P . \text { oertlii }+ \text { C. carpathica })+(C . \text { pseudodiebeli }+(C \text {. samueli }+(C \text {. orchardi }+(E . \text { miettoi } \\
\text { sp. nov. }+((E . \text { spatulata }+E \text {. heinzi sp. nov. })+(E \text {. vialovi }+E \text {. quadrata }+(E . \\
\text { praetriangularis }+(E \text {. uniformis }+(E \text {. trangularis }+E \text {. rigoi })))))))))\end{array}$ & Char. 16: $0 \rightarrow 1$; Char. $34: 0 \rightarrow 1$ \\
\hline 18 & (P. oertlii + C. carpathica $)$ & Char. 13: $1 \rightarrow 0$; Char. 22: $1 \rightarrow 0$; Char. $46: 1 \rightarrow 0$. \\
\hline 19 & $\begin{array}{l}\text { (C. pseudodiebeli }+(\text { C. samueli }+(C . \text { orchardi }+(\text { E. mietto } \mathrm{sp} . \text { nov. }+((E . \text { spatulata }+E \text {. } \\
\text { heinzi } \mathrm{sp} \text {. nov. })+(E . \text { vialovi }+ \text { E. quadrata }+(E \text {. praetriangularis }+(E . \text { uniformis }+(E . \\
\text { trangularis }+ \text { E. rigoi }))))))))\end{array}$ & Char. $40: 0 \rightarrow 1 ;$ Char. $47: 0 \rightarrow 1$ \\
\hline 20 & $\begin{array}{l}\text { (C. samueli }+(C . \text { orchardi }+(\text { E. miettoi sp. nov. }+((\text { E. spatulata }+ \text { E. heinzi } \mathrm{sp} . \text { nov. })+(E . \\
\text { vialovi }+E \text {. quadrata }+(E \text {. praetriangularis }+(E . \text { uniformis }+(E . \text { trangularis }+E . \\
\text { rigoi })))))))\end{array}$ & Char. $21: 0 \rightarrow 1$; Char. $23: 0 \rightarrow 1$; Char. $24: 0 \rightarrow 1$. \\
\hline 21 & $\begin{array}{l}(C . \text { orchardi }+(E . \text { miettoi } \mathrm{sp} . \text { nov. }+((E . \text { spatulata }+E \text {. heinzi sp. nov. })+(E . \text { vialovi }+E . \\
\text { quadrata }+(E \text {. praetriangularis }+(\text { E. uniformis }+(E \text {. trangularis }+E \text {. rigoi }))))))\end{array}$ & Char. $28: 0 \rightarrow 1$; Char. $38: 0 \rightarrow 1$; Char. $59: 0 \rightarrow 1$. \\
\hline 22 & $\begin{array}{l}\text { Epigondolella: }(E \text {. miettoi sp. nov. }+((E \text {. spatulata }+ \text { E. heinzi sp. nov. })+(E \text {. vialovi }+ \\
\text { E. quadrata }+(\text { E. praetriangularis }+(\text { E. uniformis }+(\text { E. trangularis }+ \text { E. rigoi })))))\end{array}$ & $\begin{array}{l}\text { Char. } 1: 0 \rightarrow 1 ; \text { Char. } 14: 0 \rightarrow 1 ; \text { Char. } 41: 0 \rightarrow 1 \text {; } \\
\text { Char. } 43: 0 \rightarrow 1\end{array}$ \\
\hline 23 & $\begin{array}{l}((E \text {. spatulata }+E . \text { heinzi } \mathrm{sp} . \text { nov. })+(E . \text { vialovi }+E \text {. quadrata }+(E \text {. praetriangularis }+(E . \\
\text { uniformis }+(E \text {. trangularis }+ \text { E. rigoi })))))\end{array}$ & $\begin{array}{l}\text { Char. } 6: 0 \rightarrow 1 \text {; Char. } 20: 0 \rightarrow 1 \text {; Char. } 48: 0 \rightarrow 1 \text {; } \\
\text { Char. } 50: 0 \rightarrow 1\end{array}$ \\
\hline 24 & (E. spatulata $+E$. heinzi sp. nov.) & Char. $16: 1 \rightarrow 0$; Char. $17: 1 \rightarrow 0$; Char. $58: 1 \rightarrow 0$. \\
\hline 25 & $\begin{array}{l}(E . \text { vialovi }+E \text {. quadrata }+(E \text {. praetriangularis }+(E \text {. uniformis }+(E \text {. trangularis }+E \text {. } \\
\text { rigoi }))))\end{array}$ & Char. $52: 0 \rightarrow 1$; Char. $53: 0 \rightarrow 1$; Char. $56: 0 \rightarrow 1$. \\
\hline 26 & $(E$. praetriangularis $+(E$. uniformis $+($ E. trangularis + E. rigoi $)))$ & Char. $36: 0 \rightarrow 1$ \\
\hline 27 & (E. uniformis $+(E$. trangularis $+E$. rigoi $))$ & Char. 24: $1 \rightarrow 0$; Char. $49: 0 \rightarrow 1$. \\
\hline 28 & $($ E. trangularis $+E$. rigoi $)$ & Char. $44: 0 \rightarrow 1$ \\
\hline
\end{tabular}

